\title{
HZ. ÂDEM-İBLÎS KISSASINI NÜZÛL-SÎRET BAĞLAMINDA OKUMAK
}

\section{Reading the Anecdote of Hz. Âdem-İblîs in the Context of Revelation- Personality}

\section{Sami KILINÇLI*}

Makale Bilgileri

$\begin{array}{ll}\text { Geliş Tarihi: } & 09.10 .2020 \\ \text { Kabul Tarihi: } & 11.12 .2020 \\ \text { Yayın Tarihi: } & 25.12 .2020\end{array}$

\begin{abstract}
Özet
Kendini mübîn ve hidâyet kaynağı olarak tanıtan Kur'an'ı Kerim'in anlaşılması ve yorumlanmasıyla ilgili birçok metot uygulanmakta ve tartışılmaktadır. Kur'an'ın büyük bir yekûnunu tutan kıssaların nasıl anlaşılması gerektiği de tartışılan konulardandır. Kıssalar genellikle farklı sûrelerde anlatılan parçalarının bir araya getirilip bütüne ulaşma çabasıyla anlaşılmaya çalışılmaktadır. Kur'an-ı Kerim hikmetli bir kitap olduğu için konuları muhataplara en uygun zamanda en doğru üslupla anlatmaktadır. Ancak bazı âyetlerin, konuların hikmetinin keşfedilmesi zor olabilmektedir. Kur'an aynı zamanda hidâyet rehberi olan mesajlar bütünüdür. Bu bütünlügün izah edilmesi için âyet ve sûreler arasındaki tenâsübe dair mushaf tertibi temelinde çalışmalar yapılmaktadır. Söz konusu çalışmalar tefsir birikimine önemli katkılar sağlamakla birlikte Kur'an'ın asıl tenâsübü nüzul ortamı ve muhataplarıla olduğu için münâsebâtu'l Kur'an çalışmalarında bu hususun göz ardı edilmemesi gerektiği anlaşılmaktadır. Hz. Âdem-İblìs kıssası Mekkî sûreler ağırlıklı olmak üzere hem Mekkî hem de Medenî sûrelerde anlatılmaktadır. Kıssanın farklı bölümlerinde meleklerin aksine, kibir ve inadından dolayı iblisin Hz. Âdem'e secde etmemesi, Hz. Âdem ve Havvâ'yı avret yerlerinin açı̆̆a çıkması için kandırması, lanetlenmesi, insanlar Hak yoldan uzaklaştırmak için kıyamete kadar izin alması, bu hedefine ulaşmak için farklı metotlarla mücadele edeceği, meleklerin Hz. Âdem'in halife kılınmasına tepkileri, hatalarını anlamaları gibi konular anlatılmaktadır. Kıssanın bölümleri nüzul-sîret bağlamında okunmadığında kıssada tekrarların yapıldığı düşünülmektedir. Hâlbuki ilgili âyetleri kendi bağlamında ve muhatapları çerçevesinde anladığımızda her parçanın nüzûl şartlarında özel anlamının olduğu görülmektedir. Mekkî sûrelerdeki bölümlerde İslam'a inanmayan müşriklerin inat, haset ve kibirlerinin şeytanın tutumuna benzediği, şeytanı velî edinen inkârcıların ona uyarak Kâbe'yi çıplak tavaf ettikleri, yeme ve içmede yanlış kurallar koyduklar, ilahlaştırdıkları melekler Allah'in emrine itaat ederken kendilerinin şeytanın yoluna tabi oldukları, kâfir oldukları, mahşerde ilahlaştırdıkları cinlerin kendilerine yardımcı olamayacağı gibi hususlar anlatılmakta ve müşriklerin tövbeye davet edildiği anlaşılmaktadır. Kissada Hz. Peygamber'e hak yolda sebat ve azim göstermesi gerektiği, Hz. Âdem gibi olmaması gerektiği de açıklanmaktadır. Bu sûrelerdeki anlatım metotları Kur'an'ın dinamik dil ve üslubunun muhataplara göre nasıl değiştiğini de göstermektedir. Kıssanın Bakara Sûresindeki bölümünde Mekkî sûrelerde konu edilmeyen Allah'in halife olarak var etmesi, ona isimleri ögrretmesi, meleklerin itirazı ve hatalarını anlamaları konularina yer verilmektedir. Bu âyetlerin öncelikli muhatapları risâletin, ilahî temsilciğin ümmî Araplara verilmesini kıskanan, bundan dolayı İslam'a girmeyip Hz. Peygamber ve Müslümanlara düşmanlık yapan Yahudilerdir. Hz. Peygamber sadece Yahudi kaynaklarinda yazılı olan, başkalarının bilmediği tarihi olaylan İsrailoğullarına anlattığından Yahudi âlimleri onun peygamber olduğunu anladıkları halde yine de inkâr etmekteydiler. Bundan dolayı da âyetlerin öncelikli olmuşlardır. Hz. Âdem-İblîs kıssasında birçok bilgi tekrar ediliyormuş gibi gözükse de her bağlamda muhatap ve verilmek istenen mesajların değiştiği dolayısıyla tekrarın bulunmadığ görülmektedir. Çalışmanın amacı Kur'an'daki kıssaların nüzûl sürecini dikkate alarak okunmasının önemini, Hz. Âdemiblîs kıssanın muhataplarını ve verdiği mesajları tespit etmek olduğu için makalede Hz. Âdem'in yaratılışı ve yaşadiğı cennet gibi konularda klasik ve modern dönemde yaşanan tartışmalara girilmemiştir.
\end{abstract}

Anahtar Kelimeler: Tefsir, Bağlam, Nüzûl, Hz. Âdem, İblîs

\footnotetext{
* Doç. Dr., Çukurova Üniversitesi/İlahiyat Fakültesi/Temel İslam Bilimleri Bölümü/Tefsir Anabilim Dalı, kilinclisami01@gmail.com, https://orcid.org/0000-0002-8232-7474
} 


\section{Giriş}

Cahiliye dönemini yaşayan Arap toplumunu 1slah ederek örnek toplum haline getirmek için inzal edilen Kur'an yirmi üç yıllık süreçte tedrîcen nazil olmuştur. Hz. Ebu Bekir döneminde toplanan ve $\mathrm{Hz}$. Osman döneminde çoğaltılan mushaflar nüzûl sırasına göre tertip edilmediği için tefsir geleneği de mushaf tertibi esas alınarak teşekkül etmiştir. Müfessirler âyetleri tefsir ederken mümkün olduğu kadar nüzûl sürecini dikkate almışlarsa da Kur'an metnin yapısı ve müfessirin öncelikleri gereği birçok konuda âyetlerin sîretle uyumuna, ilk muhatapların anlam dünyalarındaki karş1lılarına yeteri kadar dikkat edilememiştir.

Elmalılı (1878-1942) Kur'an'ın farklı muhataplara mesajlarını, en isabetli üslupla anlatmasını şu şekilde açıklamaktadır: "Kur'an manasını en kolay ve açık sûrette anlatan, tekellüfsüz, tasannüsüz su gibi akan, nur gibi parıldayan bir kitâb-1 mübîndir. O, kendisini bütün insanlığa duyurmak ve anlatmak için nâzil olmuş ve duyurmuştur. Bir manası inkişâf ederken arkasından bir mana daha, arkasından bir mana da ilh...yüz gösterir. Mü'mine hitap ederken, kâfire bir inzâr firlatır. Kâfiri inzâr ederken mü'mine bir tebşir nüktesi uzatır. Avama hitap ederken, havassı düşündürür. Âlime söylerken cahile dinletir. Cahile söylerken âlime dokundurur. Geçmişten bahsederken geleceği gösterir. Bu günü tasvir ederken yarını anlatır. En sade müşahedelerden en yüksek hakikatlere götürür. Mü'mine gaybı anlatırken, kâfirleri halden bîzar eder. Ve bütün bunları hâle, makama, mekâna, zamana, mevzûa göre en uygun, en ra'na kelimelerle ifade eder."1

Bu şekilde insanı kuşatan ve hidâyete ulasstıran "Kur'an-1 Kerim’in eldeki verilerden hareketle nüzûl sırasina göre tefsir edilmesi, Peygamber döneminde İslam toplumunun gelişme aşamaları, ana hatlarıyla dini hükümlerin iniş sıralarını belirleme bakımında önem arz etmektedir."2

"Kur'ân kıssaları müşrik Araplar ve ehl-i kitaptan meydana gelen ilk muhataplar tarafından bilinmekte idi. Ancak müşrikler ile ehl-i kitabın kıssa bilgileri aynı düzeyde değildi. Ayrıca kıssaların bilinmeyen yönlerinin de âyetlerde anlatılmış olması $\mathrm{Hz}$. Peygamber"cin nübüvvetini destekler niteliktedir. ${ }^{3}$

Şâtıbî'nin (ö. 790/1388) ifadesiyle “Kur'an'da zikredilen kıssalar Hz. Peygamber’in kâfirlerin inadı ve kendisini çeşitli iftiralarla yalanlamaları karşısında çektiği sıkıntılardan dolayı teselli edilmesi ve kalbinin takviye edilmesi içindir. Bundan dolayıdır ki, zikredilen kıssalar Hz. Peygamber'in karşılaştığı durumlara göre gelmiştir. Bu yüzden de aynı kıssa halin farklılığına göre farklı şekillerde anlatılmıştır. Hepsi de haktır ve vâkîdir; sıhhatlerinde

\footnotetext{
${ }^{1}$ Elmalı1ı M. Hamdi Yazır. Hak Dini Kur'an Dili, I-X, (İstanbul: Yenda Yayın-Dağıtım, 2000), I, 9.

${ }^{2}$ M. Sait Şimşek, Kur'an'ın Ana Konuları, (İstanbul: Beyan Yay. 2001), s. 9.

${ }^{3}$ Halil Aldemir, "Vahiy Öncesi Kur'an Kıssalarının Bilinebilirliği” Din Bilimleri Akademik Araştırma Dergisi, 11 (1), (ss. 165-218), s. 217.
} 
herhangi bir kuşku yoktur. Kur'an'ı anlamak isteyenin bu yaklaşım tarzını benimsenmesi gerekmektedir." 4

Mustafa Öztürk’e göre “Kur’an'daki kıssalar insanoğlunun her çağda karşılaştığ1 olaylar, olgular ve prototip figürlerle ilgili çarpıcı anekdotlar içerir. Geçmiş peygamberler ve toplumlarla ilgili kıssalar ilk bakışta mazinin derinliklerine dair anlatımlar gibi görünse de aslında hep şimdiye işaret eder niteliktedir. Nüzûl dönemindeki yaşanmışlıklar dikkate alındığında, kıssaların işaret ettiği 'şimdi' Hz. Peygamber ve sîretine karş1lık gelir. Daha açıkçası Nûh, Hûd, Salih, İbrahim, Musa gibi birçok peygamberin kendi kavimleriyle mücadelelerine atıfta bulunan kıssalar $\mathrm{Hz}$. Peygamber'in mücadelesine geçmişten ayna tutar gibidir." "Kıssalardaki esas mana ve maksatları daha sağlıklı bir şekilde tespit edebilmek için, Hz. Peygamber’in sîretini ve nüzûl sürecindeki Mekke-Medine dönemlerini göz önünde bulundurmak gerekir. Zira vahyin nüzulü tarih, toplum, zaman ve mekân gibi unsurlardan bağımsız olarak boşlukta vaki olmadığına göre Kur'an'daki her kıssa evvel emirde nüzûl ortamıyla doğrudan irtibatlı manalar içerir."6

Kur'an'in muhtevasında önemli bir yer tutan kıssalar ilahi mesajların doğrudan ve dolaylı muhataplarına ulaştırılmasında çok ciddi bir işlev üstlenmişlerdir. Kur'an'da diğer peygamber kıssalarına göre Hz. Yusuf kıssası bir bütünlük içinde anlatılmıştır. Hz. Musa ve Hz. İbrahim başta olmak üzere diğer kıssalar farklı sûrelerde bölümler halinde anlatılmıştır. İzzet Derveze'ye (1888-1984) göre “Kur'an'ın Mekke ve Medine dönemlerinde inen kısımlarıyla kullanılan yardımcı unsurlar (kıssalar) arasında bir ahenk ve uyum da bulunmaktadır. Kur'an'daki kıssaların ifade tarzları ve hedefleri, Kur'an'ın cihad, hukuk, tartışma ve Peygamberimizin pratik hayatında yaşanan olaylarla ilgili açıklamaların yer aldığı ifade tarzı ve hedefleriyle uyumludur. Öyle ki; Kur'an'1 inceleyen bir kimse bu saydığımız hususların da öğüt, hatırlatma, bazı noktalara dikkat çekme, teşvik etme, sakındırma, eğitim, terbiye ve yasama maksatlarıyla yer aldığını görecektir. Aynı zamanda kıssaların tarihsel anlatım üslubu ve amacıyla yer almadıklarını görecektir.”7

“Kur'an'daki kıssalar Rasul ve Nebilerin -mukaddes tarihi- çerçevesinde $\mathrm{Hz}$. Peygamber'in davetinin geçmişini, halini ve geleceğini gösteren bir ayna konumundadır. Bu da Kur'an'in oluşum süreci ile Hz. Peygamber'in daveti arasındaki uyumu ve kıssaların Kur'an'’n nüzûl tertibi çerçevesinde değerlendirmenin önemini anlatmaktadır.”8

Ulûmu'l-Kur'an kitaplarında Mekkî ve Medenî âyet ve sûrelerin özellikleri anlatılırken Zerkeşî (ö. 794/1392) ve Suyûtî (ö. 911/1505) Mekkî ve Medenî sûrelerin genel hususiyetlerinden biri olarak, "Bakara sûresi hariç, Âdem-İblîs kıssasını içeren tüm sûreler

\footnotetext{
${ }^{4}$ Ebu İshak eş-Ŝâtıbî, el-Muvâfakât, çev. Mehmed Erdoğan, (İstanbul: İz Yayıncılık, 1999), III, 405.

${ }^{5}$ Mustafa Öztürk, Kur'an Kissalarinın Mahiyeti, (İstanbul: Kuramer Yay. 2016), 11.

${ }^{6}$ Öztürk, Kur'an Kissalarinın Mahiyeti, 214.

7 İzzet Derveze, Kur'anu'l-Mecîd, trc. Vahdettin İnce (İstanbul: Ekin Yayınları, 1997), 156.

8 M. Âbid el-Câbirî, Medhal ile'l-Kur'âni'l-Kerîm, (Beyrût, Merkezu dirâsâti'l-Vahdeti'l-Arabî, 2007), 257.
} 
Mekkîdir" tespitini yapmaktadırlar.9 "Ancak nüzûl tarihiyle ilgili bu bilgi sadece Âdem-İblîs kıssasının on üç yıllık Mekke döneminin herhangi bir safhasında nazil olduğunu belirtmekte, dolayısıyla söz konusu kıssayı muhtevi âyetlerin on üç yıllık dönemin hangi safhasında indiği ve ilk hitap çevresindeki muhatap kitlenin zihninde neye karş1lık geldiği meselesini açıklığa kavuşturacak özellikte görünmemektedir. Oysa kıssalardaki aslî mana ve maksatların tespiti söz konusu olduğunda, nüzûl ve siret safhasının ayrıntılı olarak bilinmesi gerekmektedir." 10 "Kronolojik sûre tertibi oluşturma çalışmalarına dayanak teşkil eden rivâyetler çoğunlukla esbâb-1 nüzûl ve Mekkî - Medenî hakkındaki rivâyetlerdir... Ancak sahâbe ve tâbiûn tarafından bilinebilecek olan bu tür rivâyetler, kaynaklarımıza sistemli bir şekilde geçirilemediğinden, sıhhat derecesine bakılmaksızın birbirine muhalif birçok bilginin aynı kaynaklarda bir araya getirildiği görülmektedir."11 Bu durum Kur'an'dan herhangi bir konuyu nüzûl sırasına göre ele almanın kolay bir husus olmadığını göstermektedir. Bu çalışmada âyet ve sûrelerin nüzul sıralamasına dair tartışmalara girmeden konumuzla ilgili âyetleri $\mathrm{Hz}$. Osman'a atfedilen nüzul sıralamas1 ${ }^{12}$ doğrultusunda ele alacağız. Bu tertibe göre Hz. Âdem-iblîs kıssası Mekkî sûrelerden 38. sûre Sâd, 38/7185; 39. sûre A'râf, 7/11-27; 45. sûre Tâhâ, 20/115-123; 50. sûre İsrâ, 17/61-66; 54. sûre Hicr, 15/26-44; 69. Sûre Kehf, 18/50-51. âyetlerde anlatılmaktadır. Kıssa Medenî sûrelerden sadece 87. sûre Bakara, 2/30-39. anlatılmaktadır.

Nüzûl ortam1-sûre-kıssa ilişkisini araştıran İshak Doğan'a göre "Kıssalarla ilgili yapılmış çalışmalara baktığımızda, Kur'an'da özellikle geçmiş peygamberlerden bahseden âyetlerin klasik şekilde birbirini tamamlar tarzda ele alındığını ve bir nevi Kur'an'a göre peygamberler tarihi çalışmalarının ortaya konulduğunu görürüz. Örneğin Bakara, A'raf, Hicr, İsrâ, Tâhâ ve Sâd sûrelerinde, çeşitli yönleriyle anlatılan Hz. Âdem kıssası, ilgili bölümlerin bir araya getirilip kompoze edilmesi şeklinde değerlendirilmiş, Hz. Âdem'in yaratılışından dünyaya gönderilmesine kadar olan bölüm bir bütün halinde sunulmuş, ancak bahsi geçen sûrelerde $\mathrm{Hz}$. Âdem ile ilgili o pasajların niçin yer aldığı, pasajlar arasındaki ayrıntıların hikmetleri üzerinde düşünülmemiş, kıssa-sûre ilişkisi, kıssanın müslümanlar üzerindeki etkisi ya da verdiği mesaj incelemeye alınmamıştır. ${ }^{13}$

Bu çalışmada Kur'an'da farklı sûrelerinde anlatılan Hz. Âdem-İblîs kıssasının nüzûlsîret ilişkisi içerisinde doğrudan ve dolaylı muhatapları ile bunlara yönelik mesajları tespit edilmeye çalışılacaktır. Çalışmada müfessirlerin kıssanın nüzûl ortamındaki mesajına ne kadar yoğunlaşıp yoğunlaşmadıklarını, bağlam dışı yorumlara gidip gitmediklerine de değinilecektir.

\footnotetext{
9 Bedreddin Muhammed b. Abdullah ez-Zerkeşî. el-Burhân fí 'Ulumi'l-Kur'an. thk. Mustafa Abdulkadir Atâ. I-IV, (Beyrut: Dâru'l-Kütübi'l-İlmiyye, 1428/2007), I, 134; Celaleddin Abdurrahman es-Suyûtî,el-îtkan fi Ulumi'lKur'an, thk. Ahmed b. Ali, (Kahire: Dâru'l-Hadis, 2006), I, 74.

10 Öztürk, Kur'an Kissalarının Mahiyeti, 215.

11 Burhan Çonkor, "Kronolojik Sûre Tertibi Çalışmalarına Etkisi Bağlamında İhtilafa Sebep Olan Nüzûl Rivâyetleri Üzerine Bir Değerlendirme”. Mütefekkir, 5 (9), (ss. 47-64), s. 50.

$12 \mathrm{~Hz}$. Osman'a izafe edilen nüzûl sıralaması için bk. İsmail Cerrahoğlu, Tefsir Usûlü, (Ankara: Türkiye Diyanet Vakfı Yayınları, 1991), 84-87.

13 İshak Doğan, "Nüzûl Ortam1-Sûre-Kıssa İlişkisi (Kalem Sûresi Örneği), Din ve Bilim - Muş Alparslan Üniversitesi İslami İlimler Fakültesi Dergisi, 2(1), (ss.115-139), s. 117.
} 
“Kur’an'da özellikle peygamberlerden bahseden kıssalar, nazil olduğu zaman ve zemin itibariyle Hz. Peygamber'in (sav) ve Müslümanların ihtiyaç duyduğu konulardan bahsetmektedir. Dolayısıyla kıssalar, ibret kaynağı olduğu gibi, kronolojik olarak sıralanıp okunduğunda örnek risalet ve tebliğin geçirdiği aşamaları da gözler önüne sermektedir"14 $\mathrm{Bu}$ şekilde tarihten seçilen örnekler Hz. Peygamber ve sahabenin duruşlarının sabitlenmesi, teselli edilmeleri ve eğitilmeleri için kullanılmış olmaktadır.

\section{A. Mekkî Surelerde Hz. Âdem-İblîs Kissası}

\section{Sa'd Sûresi 71-85. Âyetler}

Nüzûl tertibine göre Hz. Âdem-iblis kıssasının ilk anlatıldığı yerdir. ${ }^{15}$ Sâd sûresinde Hz. Dâvûd ve Süleyman'ın kıssaları, imtihanları, sabırlarından dolayı övülmeleri ve dünyada kendilerine bahşedilen lütuflardan sonra 51-64. âyetlerde bu peygamberlerin ve diğer muttakilerin girecekleri cennet gibi konular anlatıldıktan sonra 65-70. âyetlerde $\mathrm{Hz}$. Peygamber'in müşriklere tevhidi tebliğ etmesi, Kur'an'i inkârlarının yanlışlığ ve mele-i a'la'da nelerin konuşulduğunu Hz. Peygamber'in bilmediği anlatılmaktadır. 71-85. âyetlerde ise Hz. Âdem'in yaratılışı, Allah Teâlâ'nın ruhundan üflemesi, secde emri, şeytanın isyanı, kıyamete kadar mühlet alması, ihlasa erdirilenlere zarar vermeyeceğini beyanı ve Yüce Allah'ın bunu teyit ederek şeytanı ve takipçilerini cehenneme dolduracağını açıklaması anlatılmaktadir.

Âyetlerin bağlamından Hz. Âdem-iblîs kıssasının müşriklere yönelik anlatıldığ anlaşılmaktadır. Mele-i a'lâ'daki tartışma konusu Allah Teâlâ'nın yeryüzünde halife yaratacağım buyurması üzerine meleklerin "Niçin kan dökecek, fesat çıkaracak birini yaratıyorsun?” şeklindeki itirazlarıdır. Müşrikler de Hz. Peygamber’i inkârlarıyla şeytana tabi oldukları için cehennemlik olmuşlardır. ${ }^{16}$

$\mathrm{Bu}$ kıssanın amacı haset ve kibirden men etmektir. Şeytan gibi müşrikler de $\mathrm{Hz}$. Peygamberle bu iki kötü huydan dolayı mücadele etmişlerdi. Bu sûredeki kıssanın bu şekli Kureyş’in ileri gelenlerinin “Kur'an'in indirileceği insan tek sen mi kalmışsın?” şeklindeki alaylarına bir cevaptır. Kureyş’in ileri gelenlerine verilen diğer bir cevap ise şu şekildedir: "Sizlerin Muhammed'e gösterdiği kibir ve hased, tıpkı İblîs’in Âdem'e gösterdiği kibir ve hased gibidir. İblîs de Allah'n emirlerine karşı gelmiş ve Allah, Âdem’i halife tayin ettiği için secde etmekten kaçınmıştı. Şimdi sizler de Allah'in emirlerine karşı geliyor ve Allah onu

\footnotetext{
14 İshak Doğan, "Nüzûl Ortam1-Sûre-Kıssa İlişkisi (Kalem Sûresi Örneği)", s. 118. Bu tür örnek bir çalışma için bkz. Mahmut Ay, "Kur'an Kıssalarını Hz. Muhammed'in (sav) Kıssası Paralelinde Okumak", Kur'an Nüzûlünün Medine Dönemi Sempozyumu, X. Tefsir Akademisyenleri Buluşması Sempozyum Bildirileri, (Kahramanmaraş, 17-19 Mayıs 2013), ss. 126-142; Öztürk, Kur'an Kissalarinın Mahiyeti, 233-240.

15 İbn Âsûr, et-Tahrîr, XXIII, 297.

16 Ebu'l-Hasen Mukâtil b. Süleyman. Tefsîru Mukâtil b. Süleyman. thk. Ahmed Ferid. (Beyrut: Dâru'l-Kütübi'lİlmiyye, 1424/2003), III, 124; Ebû Ca'fer Muhammed b. Cerîr et-Taberî, Câmi'u'l-Beyân 'an Te'vîli Âyi'lKur'an.Thk. Abdullah b. Abdulmuhsin et-Türkî. (Beyrut: Dâru'l-Kütübil-İlmiyye, 2005), X, 605; Mâturîdî, Te'vilâtu Ehli's-Sünne, Thk. Fâtıma Yûsuf el Haymî, (Beyrût: Müessetu'r-Risâle, 1325/2004), VI, 283; Ebu'lKâsım Mahmûd b. Ömer ez-Zemahșerî. el-Keșsâf 'an Hakâiki't-Tenzîl. I-IV, (Beyrut: Dâru'l-Ma'rife, 2008), III, 106; Ebü'l-Ferec Cemâlüddîn Abdurrahmân b. Alî İbnü'l-Cevzî. Zâdü'l-Mesîr fì îlmi't-Tefsîr, thk. Abdurrezzak el-Mecdî, I-IV, (Beyrut: Dâru'l-Kütübi'l-Arabî, 1431/2010), II, 582; Abdullah b. Muhammed b. Ahmed el-Kurtûbî. elCâmi'uli Ahkâmi'l-Kur'ân. Thk. Abdullah b. Abdu'l-Hasen et-Türkî. I-XXIV, (Beyrut: Müessetu'r-Risale, 1427/2006), XVIII, 236.
} 
peygamber olarak tayin ettiği halde, Muhammed'e tabi olmuyor ve karşı çıkıyorsunuz. Yaptıklarınıza devam ederseniz, siz de şeytan gibi dünyada lanetlenir, ahirette cehenneme girersiniz." Bu kıssada ayrıca iki husus daha vurgulanmıştır. 1. Dünya hayatında Allah'a isyan eden kimse, aslında İblîs'in tuzağına düşmüştür. 2. Allah'a karşı büyüklenen kimse Allah’ın büyük nefretini kazanır ve böyle bir kul için af söz konusu değildir. ${ }^{17}$

75. âyette Allah Teâlâ'nın şeytana "Ellerimle yarattığım Âdem'e niçin secde etmedin? Yoksa sen kibirlenip, büyüklenenlerden mi oldun" sorusuna şeytan 76. âyette "Ben ondan hayırlıyım, beni ateşten, onu çamurdan yarattın" diye cevap vermektedir. Allah Teâlâ'nın "Büyüklenenlerden mi oldun"18 "Sen daha önce Rabbine karş1 kibir ve yücelik sahibi mi oldun?” sorusuna şeytan, "Ben sana karşı kibirlenmedim, büyüklenmedim. Ancak sonuçta topraktan yaratılan Âdem'den daha üstünüm” dedi. Bu âyetle bu surenin girişinde müşriklerin "Vahiy içimizden Muhammed'e mi indirildi?"19 şeklinde Hz. Muhammed'i küçümseyen, ona iman ve itaat etmeyen tavırlarına kınama vardır. Şeytan nasıl secde etmeyerek kâfirlerden oldu ve lanetlendi ise onun karakterine bürünen müşrikler de aynı akıbete uğrayacaklardır hâkezâ.” $20 \mathrm{Bu}$ âyetler kötü niyetli, kalpleri hastalıklı ve kibirli müşriklerin inkarlarından üzülen, rahatsız olan Hz. Peygamber ve sahabileri teselli etmek için indirilmiştir. ${ }^{21}$

Kıssanın bağlamından ve müfessirlerin yorumlarından bu âyetlerin muhataplarının müşrikler olduğu, onların eğer kibir ve hasetlerini bırakarak Hz. Peygamber'e iman etmezlerse kâfirler olarak şeytanın taraftarları olacakları anlatılarak tövbeye davet edilmişlerdir. Kıssanın içeriği ile Mekke'de müşriklerin $\mathrm{Hz}$. Peygamber ve davetine gösterdikleri tepkinin birebir örtüştüğü görülmektedir. Müşriklerin ilahlaştırdıkları meleklerin Hz. Âdem'e secde etmelerinin anlatılması "Siz de melekler gibi Allah'a itaat edin, elçisi Hz. Muhammed'e iman edin" mesajı vermiş olmalıdır. Bu mesajlar kendilerini ehlullah, Hz. İbrahim’in takipçileri, Kâbe'nin koruyucuları olarak tanımlayan Mekkelilere oldukça ağır gelmiş olmalıdır.

\section{A'râf, 7/11-27. Âyetler}

A'râf Sûresi 11-27. âyetlerde Hz. Âdem’in yaratıllsş1, secde konusu, cennette şeytanın Hz. Âdem ve Havvâ'yı avret mahallerinin açılması için dostmuş gibi gözükerek melekleşme ve ebedi yaşamanın cazibesiyle kandırması, meyveyi yediklerinde üstlerinin açılması nihayet kendilerine "kıyafet ve takva elbisesinin lütfedildiği”" anlatılmaktadır. Ayrıca insanlara da

\footnotetext{
17 Taberî, Câmi'u'l-Beyân, X, 606; Fahruddîn İbn Ziyâuddîn b. Ömer Muhammed er-Râzî. Mefâtihu'l-Gayb. IXXXII, (Beyrut: Dâru'l-Fikr, 1401/1981), XXVI, 227; Ebû Hayyân Muhammed b. Yusuf. el-Bahru'l-muhît, thk. Âdil Ahmed Abdulmansur v.d., (Beyrut: Dâru'l-Kütübi'l-İlmiyye, 1413/1993), VII, 391; Ebû Hafs Ömer b. Alib. 'Âdil. elLubâb fì 'Ulûmu'l-kitâb. thk. Adil Ahmet Abdulmevcûd v.d., I-XX, (Beyrut: Dâru'l-Kütübi'l-i̇lmiyye, 1419/1998), XVI, 453; Ebu'l-A'lâ el-Mevdûdî. Tefhimu'l-Kur'an. trc. Muhammed Han Kayanî v.dğr. 2. Bask1. I-VII, (İstanbul: İnsan Yayınları, 1991), $\mathrm{V}, 89-90$.

18 Mukâtil, Tefsîr, III, 125; İbnu'l-Cevzî, Zâdu'l-Mesîr, IV, 583.

19 Sâd, 38/8.

20 Taberî, Câmi'u'l-Beyân, X, 606. Zemahşerî, Keşşâf, IV, 109.

${ }^{21}$ İzzet Derveze, et-Tefsîru'l-Hadîs. (Tunus: Dâru'l-Garbi'l-İslâmî, 1421/2008), II, 343.
} 
"Şeytan sizi anne-babanızı kandırdığı gibi kandırmasın, o ve dostları size görmediğiniz şekilde saldırıp müdahale ederler." buyrulmaktadır.

Şeytan, İslam öncesi Arapları örtünmenin, sadece süslenmek ve vücudu hava şartlarından korumak manasına geldiği inancına sevk ederek baştan çıkarmıştı. Cahiliye döneminde Kâbe'yi Kureyş/Hums ehli giyinik, diğerleri çıplak tavaf diyorlardı. Müşrikler "Bunu Allah emretti" diyorlard1. Benî Âmir kabilesi kendilerine göre dini gerekçelerle, daha iyi kul olma adına Hac esnasında iç yağı gibi bazı yiyeceklerden perhiz ediyorlardı. 27. âyet sonrası dört âyet Kureyş hakkında nazil olmuştur. Kureyş'e ve tüm insanlara "Çıplaklık konusunda şeytana itaat etmeyin, anne-babanızın düştüğü hataya düşmeyin" buyrularak takva elbisesinin, iman ve hayânın Allah'a yaklaşma açısından zahiri kıyafetlerden, süslenme ve güzellikten daha hayırlı olduğu açıklanmıştır. Müşrikler çıplak tavafı Allah'ın emrettiğini söylüyorlardı. Hâlbuki onların velisi şeytan idi fakat onlar hâlâ kendilerini doğru yolda zannediyorlar. Bu âyetlerle insanlar örtünmede fiziksel işlevden ziyade ahlaki işleve önem verilmesi ve şeytana tabi olmama konularında uyarılmışlardır. Bu âyetlerle sahabilere "Siz Kâbe'ye yöneldiğinizde, her tavaf ve namazında giyinin çıplak olmayın. Yeme içme konusunda belirlediğiniz helal haramları bırakın, Allah'ın sınırlarını aşmayın, israf etmeyin. Bunları yapmanız haramdır. Nimetler dünyada herkese ortak ama ahirette sadece mü'minlere ait olacak. Allah açık gizli tüm fuhşiyyatı yasakladı" buyrulmuştur. ${ }^{22}$

Müslümanlar Kâbe'yi giyinik olarak tavaf etmeye başlayınca müşrikler onları kınadılar, ayıpladılar. Bunun üzerine 33. Âyetle Allah Teâlâ'nın gizli açık tüm fuhşiyyatı, zulmü, şirki ve Allah hakkında bilmeden konuşmayı yasakladığı beyan edildi. ${ }^{23}$

"Takva libası, duygusu ile giyinin. Hayâ hissi ve haşyetullah ile giyilen ve Allah'ın izniyle maddî manevî ayıptan, fenalıktan, zarara uğramaktan ve helak olmaktan koruyacak bu takva elbisesi hayr-1 mutlaktır. ${ }^{24}$ "Biz bu yasaklananları yapiyoruz ve Allah'tan bize ceza gelmiyor" diyenlere de her ümmete tanınan bir sürenin olduğu, bu zaman sona erdiğinde cezalandırılacakları, ecellerinin, güç ve hâkimiyetlerinin son bulacağı anlatılmıştır. ${ }^{25}$

"Bu sûre içerik olarak bir önceki sûre olan Sâd sûresi ile doğrudan bağlantılıdır. Her iki sûrenin girişinde de Kureyş'in $\mathrm{Hz}$. Muhammed'in peygamber olarak gönderilmesine tepkileri anlatılmaktadır. Bu sûredeki İblîs’in Hz. Âdem karşısındaki konumu Kureyş’in Hz. Muhammed'e olan tavrıyla irtibatlıdır. Şeytan'in kibirlenerek Hz. Âdem'e secde etmemesi

\footnotetext{
22 Taberî, Câmiu'l-Beyân, X, 81-165; Mâturîdî, Te'vilâtu Ehli’s-Sünne, II, 219-225; Ebu'l-Hasen Ali b. Ahmed elVâhidî, el-Vasît fì Tefsîri'l-Kur'âni'l-Mecîd, thk. Adil Ahmet Abdulmevcûd v.d., I-III, (Beyrut: Dâru'l-Kütübi'lİlmiyye, 1415/1994), II, 352-364; Kurtûbî, el-Câmiu' li Ahkâmi'l-Kur'ân, IX, 181-210; Mevdûdî, Tefhîmu'l-Kur'ân, I, 24-27; Elmal111, Hak Dini Kur'an Dili, IV, 76-81. İbn Âdil, el-Lübâb, 9:87-91; Derveze, et-Tefsîru'l-Hadîs, II, 375378; Abdurrahman Habenneke el-Meydânî, Meâricu't-Tefekküri ve Dekâiku't-Tedebburi, (Dımaşk: Dâru'1Kalem,1423/2002), IV, 184-187.

${ }^{23}$ Kurtûbî, el-Câmiu' li ahkâmi'l-Kur'ân, IX, 210.

${ }^{24}$ Elmalil, Hak Dini Kur'an Dili, IV, 76.

25 Elmalıl1, Hak Dini Kur'an Dili, IV, 81-83; Seyyid, Kutup. Fî Zilâli'l-Kur'an, çev. Komisyon, , I-X, (İstanbul: Dünya Yayıncılık, 1989), IV, 439; Mevdûdî, Tefhîmu'l-Kur'ân I, 27-28.
} 
Kureyş’in yönetici tabakasının kibirlenerek liderlerimiz, eşrafımız varken "Vahiy içimizden ona $\mathrm{m} 1$ geldi?26 şeklindeki tavırlarına benzemektedir." 27

$\mathrm{Bu}$ âyetlerle $\mathrm{Hz}$. Peygamber'e karşı gelenlere "Bu gittiğiniz yol şeytanın yoludur. Cinlerden ve insanlardan olan şeytanları velî edinerek sürekli ikazlarımıza rağmen, hatada ısrar etmeniz, sizin açık ve devamlı düşmanınıza teslim olduğunuzu gösteriyor. Şeytan tarafından tamamıyla rezil-rüsva hale getirilip şeytanı bekleyen aynı son ile karşılaşmadan, eğer biraz olsun sizde vicdan kalmışsa tevbe eden ilk atanız Âdem ile Havvâ'nın yoluna dönersiniz" şeklinde dersler verilmiştir. ${ }^{28}$ Aynı zamanda "Allah'ın edepsizlik ve fenalığı emretmeyeceği, onların bilmedikleri bir konuda konuşarak Allah'a iftira attıkları, şeytanın kâfirlerin velisi, amiri olduğu da" açıklanmıştır. ${ }^{29}$

$\mathrm{Bu}$ ayetlerle kendilerine göre Allah için, dindarâne bir şekilde hacceden Araplara, şeytanın velisi oldukları, yolundan gittikleri, Hz. Muhammed karşısında Hz. Âdem'e secde etmeyen şeytanın konumunda oldukları, çıplak tavaf ederek şeytanın tuzağına düştükleri ancak Hz. Âdem ve Havvâ gibi tövbe yolunu değil, şeytan gibi günahta 1srarı tercih ettikleri, dolayısıyla her ne kadar kendilerini Kâbe'nin hizmetçileri görerek haccetseler de aslında Allah ile bir ilişkilerinin kalmadığı anlatılmaktadır. Şeytan nasıl Hz. Âdem ve Havvâ'nın avret yerlerinin açılmasını sağlayarak onları hayâsızlığa sürüklemek istediyse, müşrikleri de çıplak tavafı doğruymuş gibi göstererek "Biz atalarımızdan böyle gördük, zaten Allah da bize böyle emretmisstir"30 dedirterek hayâsızlığa götürmekteydi. Âyette örtünme ihtiyacını karşılayacak elbiseden bahsedildikten sonra daha hayırlı olduğu vurgulanarak takva elbisesinden bahsedilmesi ${ }^{31}$ tesettürün ve takvanın birleştirilmesi gerektiğini göstermektedir. Çılplak tavaf etmek ve bunu savunmak şeytanın $\mathrm{Hz}$. Âdem ve Havvâ'yı kandırarak avret mahallerini açtırmasına benzemektedir. Dolayısıyla çıplak tavafı savunanlar şeytana benzemekte, bunlara tabi olanlar da şeytana tabi olmuş olamaktadırlar.

Şeytan'ın Hz. Âdem ve Havvâ'yı melekleşme ve ebedî yaşam va'diyle kandırması ${ }^{32}$ dünyevîleşmiş tüm insanlar gibi müşriklerin de dünyaya bağl11ılarını, uzun yaşama, genç kalma isteklerini ve ölümü, faniliği gündemlerinden çıkarma çabalarına işaret etmektedir. Tüm bu âyetlerde kendilerini koyu dindar gören müşriklere kendinizi her ne kadar Allah yanında değerli insanlar olarak kabul etseniz de aslında şeytanın izinden giden onun gibi isyana, günaha dalan, asiler, kâfirlersiniz buyrulmaktaydı. Bu âyet ve mesajlar hem yanlış müşrik zihninin ıslahı hem de Müslüman zihnin inşasının adımları olmakta ayrıca küçümsenen, horlanan mü'minlere Allah'ın taraftarları, hidâyet üzere olanlar sizsiniz, moralinizi bozmayın, güçlü olun anlamına da gelmekteydi.

\footnotetext{
${ }^{26} \mathrm{Sa}$ 'd, 38/8.

27 Câbirî, Medhal ile'l-Kur'âni'l-Kerîm, 293-295.

${ }^{28}$ Mevdûdî, Tefhîmu'l-Kur'ân I, 22; Derveze, et-Tefsîru'l-Hadîs, II, 371-373.

29 Elmalıl1, Hak Dini Kur'an Dili, IV, 78.

30 A'râf, $7 / 28$.

${ }^{31}$ A'râf, $7 / 26$.

${ }^{32}$ A'râf, $7 / 20$
} 
Çıplak tavafın yasaklanması tesettür konusundaki ilk âyetleri oluşturmaktadır. Bu âyetlerden sonra sahabenin giyinik tavaf etmesi ve müşriklerin bu durumu eleştirmesi Müslüman kimliğin oluşması ve yanlış uygulamalarda toplumdan ayrışmanın da örneklerinden birini oluşturmaktadır. Çıplaklık şeytanın yolundan gitmenin, ona tabi olmanın göstergesi iken giyinik tavaf, hayânın korunması Hz. Âdem ve Havvâ'nın yolundan gitmenin işareti olmaktayd. Bu konu dahi tek başına Müslüman-müşrik zihniyetin ve uygulamaların dayanakları, kökeni ve ahiretteki konumu konusunda yeteri kadar bilgi vermektedir.

Müşriklere yönelik âyetlerde Kur'an'ın doğrudan ve dolaylı bir şekilde çok açık, sert, derinden mesajlar verdiği, üslup, kelime ve kavramları çok etkili ve dikkatli seçip kullandığ1 görülmektedir. Bu açıdan Kur'an'in dil ve üslubu ve muhataplarla ilişkisi konusundaki çalışmalarda kıssalardaki konu, dil ve üsluba dikkat edilmesi gerektiği anlaşılmaktadır.

\section{Tâhâ Sûresi 115-123 Âyetler}

Tâhâ Sûresinde Hz. Peygamber'e vahiy tamamlanmadan Kur'an'ı okumada veya cevap vermede acele etmemesi ve "Rabbim ilmimi arttır" demesi emredildikten sonra Hz. Âdemİblîs kıssası anlatılmaktadır. Bu sûrede $\mathrm{Hz}$. Âdem'den ahit alındığı ancak kendisinin kararlılık göstermediği, şeytanın secde etmemesi, ebedi yaşam ve son bulmayacak mülk/saltanat va'di ile Hz. Âdem ve Havvâ'yı kandırması, meyveyi yedikten sonra avret yerlerinin açılması, tövbesi ve dünyaya gönderilmeleri anlatılmaktadır. Sonrasındaki âyetlerde ise iman etmeyenlerin ahiretteki, mahşerdeki halleri tasvir edilmektedir.

Ey Peygamber! Vahiy tamamlanmadan, anlamları tam olarak açıklanmadan sahabilere, insanlara okumada acele etme. Rabbim ilmimi, faydalanmamı arttır de. Eğer bu müşriklerin emirlerime muhalefet etmeleri, bana değil de şeytana itaat etmeleri sana ağır geliyorsa, bunların ataları olan Âdem'e "Şeytan senin ve eşinin düşmanıdır, ona itaat etmeyin, sizi cennetten çıkarmasın, mutsuz olursunuz" dediğimizde emrimize muhalefet ederek şeytana itaat etmişti. Bize verdiği ahdi terk etmiş, sabır konusunda azim, Allah'ın ahdine vefa göstermemişti. Eğer dirâyet gösterseydi kendine haset eden düşmanına itaat etmezdi. ${ }^{33} \mathrm{~Hz}$. Peygamber insanların 1slahını, kurtuluşa ermelerini çok istiyor bu konuda acele ediyordu. Bu âyetle konuyu Allah'a havale etmesi, Allah Teâlâ'nın en uygun olanı takdir edeceği bildirildi. ${ }^{34}$

Allah Teâlâ 114. âyetle Hz. Peygamber’i nisyandan temin ederek ona 'Vahyin bitmesini bekle, sonra oku, dua et. Müşrikleri tehdit etiğimiz azabın vakti gelmeden gerçekleşmesi konusunda acele etme' buyurdu. Hz. Âdem'in hatası konusunda ehli te'vilin geneli Allah'in emrini terk etmenin unutma, sehven terk etme olmadığını, eğer böyle olsaydı itabın

\footnotetext{
${ }^{33}$ Mukâtil, Tefsîr, II, 342-344; Taberî, Câmiu'l Beyân, VIII, 465-469. Ayrica bk. İbnu'l-Cevzî, Zâdu'l-Mesîr, III, 177180; Ebu'l-Hasen Alî b. Muhammed b. Habîb el-Basrî el-Mâverdî, en-Nüket ve'l-Uyûn, thk. es-Seyyid b. Abdulmansur b. Abdurrahman, I-VI, (Beyrut: Dâru'1-Kütübi'l-İlmiyye-Müessesetu'l-Kütübi's-Sekafi, ts.), III, 428431.

${ }^{34}$ Muhammed b. Tâhir b. Âşûr. Tefsiru't Tahrîr ve't-Tenvîr. I-XXX, (Tunus: Dâru Sahnûn li'n-Neşrve't-Tevzi', 1984), XVI, 316
} 
gelmeyeceğini dolayısıyla burada Allah'ın emrinin zayi edilmesinin söz konusu olduğunu ifade etmişlerdir. Eğer 'Allah'n herhangi bir peygamberinin böyle bir şeyi yapması çirkin olur, böyle düşünülmemesi gerekir' denirse konu şu şekilde açıklanabilir. Unutma iki türlüdür. Birincisi gaflet ve meşguliyetten kaynaklanan unutmadır ki bundan itab gerekir. İkincisi kendisinden kaynaklanan bir sebep olmadan meydana gelen unutmadır ki bundan dolayı itab gerekmez. Hz. Âdem'in unutması da bu şekildedir. Bu unutma Allah'in bir imtihanı sonucu O'nun iradesiyle gerçekleşmiştir. Hz. Âdem'de azmin bulunmaması sabır ve kasit bulunmamas1 anlamındadır. ${ }^{35}$ İbn Kesîr (ö. 774/1373), Hz. Âdem’in azmetmemesi, unutmasıyla ilgili olarak mahşerde Hz. Musa ile Âdem arasındaki tartışmada Hz. Musâ'nın Âdem'e "Senin günahından dolayı cennetten çıkarıldık" demesi üzerine Hz. Âdem'in "Rabbimin kaderinden dolayı $\mathrm{m}$ i beni suçluyorsun" demesini de aktarmaktadır. ${ }^{36} \mathrm{Bu}$ yönüyle Mâturîdî ve İbn Kesîr'in Hz. Âdem'in hatasını izah tarzları benzeşmektedir. İbn Âşur ise bu kıssada bir isyanın söz konusu olduğunu ancak Hz. Âdem'in o zamanda henüz peygamber olmadığını belirtiyor. ${ }^{37}$

"Eğer insan, Hz. Âdem ve firavunun sihirbazları gibi kendilerinin ezeli düşmanı olan şeytan tarafından aldatıldığını anlar ve hatasında pişman olup tövbe ederse affolur. Fakat şeytan, firavun ve Sâmirî gibi kasten yapılan isyanlar bağışlanmaz." $38 \mathrm{~Hz}$. Âdem ve Havvâ şeytanın düşmanları olduğunu bildikleri halde, bir dost ve arkadaş olarak yaklaşarak sebatsızlık etmelerine, o an için "emr'i”" unutmalarına neden olmuştur. ${ }^{39}$

"Hz. Âdem’in kasti bir isyanla değil, kararlılıktan yoksun olduğu için emre karşı geldiği anlaş1lmaktadır. O, Allah'ın emrini unuttuğu için doğru yoldan sapmıştır. Şeytanın aldatmalarında ısrar edip isyanında devam etmemiştir. Hemen tövbe etmesi de bunu göstermektedir. Hz. Âdem Allah'in kendine lütfettiği daha hayırlı şeyleri unutarak Şeytan'ın dünya malına, ziynetine yönlendirmesine aldanarak nasıl meyveye yönelmiş ise $\mathrm{Hz}$. Peygamber de Taha Suresi 131. âyette 40 anlatıldığı gibi Kureyş'in imkânlarına imreniyordu. Âyet bu konuda onu uyarmıştır. ${ }^{41}$

$\mathrm{Bu}$ bilgilerden ve pasajın bağlamından muhatabın hem $\mathrm{Hz}$. Peygamber hem de müşrikler olduğu anlaşılmaktadır. "Hz. Âdem-İblîs kıssasından önce İsrailoğulları kıssasında onların Allah'ın ahdini ihlal etmeleri anlatıldı. Burada da Hz. Âdem'in ahde uymaması anlat1liyor. Her ikisinde de ahit verilen konuyu kasitlı olarak ihmal etme durumu mevcut." 42

\footnotetext{
35 Mâturîdî, Te'vîlâtu Ehli's-Sünne, III, 310-312. Ayrıca bk. Ebü'l-Fidâ' İmâdüddîn İsmâîl b. Kesîr ed-Dimaşkî, Tefsîru'l-Kur'âni'l-'azîm. thk. Mustafa es-Seyyid v.dğr.(Kahire: Müessesetu Kurtuba, 1421/2000), IX, 371-377.

36 İbn Kesîr, Tefsîru'l-Kur'âni'l-'azîm. IX, 371-377.

37 İbn Âsûr, et-Tahrîr, XVI, 327.

${ }^{38}$ Mevdûdî, Tefhîmu'l-Kur'an, III, 279.

39 Mevdûdî, Tefhîmu'l-Kur'an, III, 281.

40 Kâfirlerden bir kısmına, onları sınamak için dünya hayatının zineti olarak verdiğimiz ve onunla kendilerini geçindirdiğimiz şeye (mal ve saltanata) sakın rağbetle bakma. Rabbinin (ahiretteki) rızkı daha hayırlı ve daha devamlidir.

${ }^{41}$ Câbirî, Medhal, 295-296.

42 İbn Âşûr, et-Tahrîr, XVI, 318-319.
} 
Râzî’ye (ö. 606/1210) göre âyetlerin genele/müşriklere insanın şeytanla mücadelesinin kadîm bir mesele olduğu ve her insanın bu bilinçle şeytanın vesveselerinden korunması gerektiği mesajlarını vermektedir. Hz. Peygamber'e Allah Teâlâ'ya olan ahdini yenilemesi, canlı tutmas1, ahdi unutturan şeytana karşı uyanık olması, ilim tahsili, hata ve unutmadan korunma konularında Rabbinden yardım istemesi ve Hz. Âdem kıssasından ders alması gerektiği vurgulanmıştır. ${ }^{43}$

Müşriklere yönelik tebliğ ve mücadelesinde Hz. Peygamber'e sabırlı olması, şeytanın dostmuş gibi gözükerek verdiği vesveselere aldanmaması, aceleci olmaması, sabır ve kararlılıkla vahye tabi olması emredilmektedir. Eğer bu kararlılığ göstermez ve aceleci olursa Hz. Âdem gibi hataya düşeceği, bu durumda da hemen tövbe etmesinin gerekliliği ona bir çıkış yolu, davranışlarını düzeltme, 1slah etme yolu olarak gösterilmektedir.

Müşriklere yönelik ise İslam'a girmelerinin gerekliliği, Hz. Peygamber’in çağrısına kör ve sağır kalmamaları, şeytana uymamaları aksi halde ahirette cezalandırılacakları anlatılmaktadır. Hz. Âdem'in şeytanın vesvesesine inanması, ahdinde sebat etmemesi durumunun anlatılmasıla da her insanın şeytana karşı bir zayıf noktasının olduğu, o çetin düşmana karşı hep teyakkuzda olunması gerektiği mesajı verilmektedir.

\section{4. İsrâ Sûresi 61-66. Âyetler}

İsrâ Sûresi 61-66. âyetlerde şeytanın Âdem'e secde etmemesi, kıyamete kadar süre verilirse pek azı hariç insanları yoldan çıkaracağı iddiası, bunun üzerine ona izin verilmesi, kendisine uyanların cehenneme atılacakları, ancak bununla beraber kullar üzerinde bir sultasının olmadığı ve vekil olarak Allah Teâlâ'nın yeterli olduğu beyan edilmektedir.

Müfessirlere göre söz konusu âyetler şunu ifade etmektedir: Ey Peygamber bu müşriklerin bâtıl yollarındaki inatları ve Rablerinin onları korkutmasına kibirlenerek inkârla karşılık vermelerinin babalarının ve kendilerinin düşmanları olan şeytanın Âdem'e olan haset ve kibrinden dolay1 "Eğer bana mühlet tanırsan onun zürriyetinin az bir kısmı hariç çoğunluğunu peşimden sürükleyeceğim”44 iddiasının gerçekleşmesi olduğunu anla, gör. 64 . âyette anlatıldığı üzere şeytanın insanların mallarında ortak olması, haramdan kazanmayı, harama harcamayı emretmesi; müşriklerin kendi kafalarına göre hayvanlarda bahîra, sâibe, vasîle ve hâmî gibi haramlar icat etmeleri; ilahlarına kurban kesmeleridir. Evlatlarda ortak olması ise zinadan doğan evlatlar, kız çocuklarını diri diri gömmeleri, öldürmeleri, küfre, şirke yönlendirmeleri, abdulhâris, abduşşems gibi isimler vermeleridir. 65. âyetteki "Kullarim üzerinde senin herhangi bir etkin yok. Rabbin vekil olarak sana yeter" âyeti ise "Emrime tabi olan ve şeytana karşı gelen kullarım üzerinde hâkimiyetin, hüccetin olamaz. Ey Peygamber! seni koruma, kollama, gözetmede Rabbin sana yeter, sen müşriklere tebliğ görevini yerine getir, onlardan herhangi birinden korkma, Allah senin muhafazanı ve zafere

\footnotetext{
${ }^{43}$ Râzî, Mefâtihu'l-Gayb. XXII, 123-124.

44 İsra, 19/62.
} 
ulaşmanı, sana yardım etmeyi garantilemiştir."45 Allah'a karşı gelen her piyade ve süvari asker de şeytanın askerleri sınıfına dâhildir. ${ }^{46}$ Şeytanın sahte va'di ise putların şefaatçi olduğuna müşrikleri inandırmasıdır. ${ }^{47}$

"Allah Teâlâ Hz. Peygamber'e müşriklerin baskı ve düşmanlıklarından bahsettikten sonra aslında bütün peygamberlerin aynı süreçlerden geçtiğini; örnek olarak ilk velisi olan Hz. Âdem'in iblîs'ten maruz kaldığı büyük sıkıntıları da bu âyetlerle anlattı. Müssrikler inat, haset ve kibirlerinden $\mathrm{Hz}$. Peygamber’i inkâr ve düşmanlık ediyor, tutarsız iddia ve eleştirilerde bulunuyorlardı. Şeytan da aynı duygularla Hz. Âdem'e düşmanlık yapmıştı. Şeytan'ın 'Ben, çamurdan yarattığın bir varlığa mı secde edeceğim?' ve "Benden daha değerli, üstün tuttuğun varlığı/Âdem'i gördün mü? ifadeleri de bu sûrede kullanılmıştır. Birinci ifade de istifhâm-1 inkarî vardır ve şeytanın secde etmeyeceğini anlatıyor. İkinci ifade ise "Benden üstün tuttuğun varlığı bana tanıt" anlamına geldiği kadar "Benden daha üstün tuttuğun varlık bu mu?” anlamında küçük görme ve tahkir içermektedir. Bu ifadenin taaccüb ve inkâr anlamına gelmesi de mümkündür. ${ }^{48}$

"Şeytanın insanlara her ne kadar çok farklı yollardan saldırması, musallat olması, etkilemesi, çok farklı güçleri olsa da Allah'ın gücü yanında bir hiç mesabesindedir. Allah Teâlâ kullarına karşı çok merhametlidir. Kullarını şeytanın her türlü iğva ve tuzaklarından korur."49 "Kendi güçlerine veya Allah'tan başka güçlere güvenenler şeytanla imtihan edildiklerinde bu sınavdan başarılı çıkamayacaklardır. ${ }^{50}$

"Müşrikler İsra ve Mi’rac olayı üzerinden büyük gürültüler kopararak "Bir insanın Mekke'de Beyt-i Makdis'e oradan da semaya yükselmesi mümkün değildir” dediler. İsramiraç ve zakkumla ilgili anlatılanlar onlar için fitne konusu oldu. Bazı iman edenler de irtidat etti. Bu bilgilerle şeytanın secde etmedikten sonra isteği üzere verilen süreden dolayı "Defol git, sana uyanları cehenneme atacağım" âyeti Kureyş’in miraçla yoldan çıkmasıyla irtibatlıdır. ${ }^{51}$ Müşriklerin akılları almadığ ve kibirlerine yediremedikleri için İsra-miracı ve Hz. Peygamber'in risaletini/hilafetini reddetmeleri ile şeytan'ın aklına uymadığı için Hz. Âdem'in yaratılmasını, halife kılınmasını, kabul etmediği için secde etmemesi ve düşmanlık yapmas1 aynı zihniyetin ürünüdür. Bundan dolayı âyetlerde müşriklerin şeytanın velisi olarak adlandırılmalarının da bir hakikati dile getirdiği anlaşılmaktadır.

Kıssanın bu sûredeki kısmı genel olarak müşriklere kısmen de Hz. Peygamber ve sahabilere hitap etmektedir. Şeytanın insanlara yönelik düşmanlığı, bütün askerleriyle saldıracağı ve tuzakları daha ayrıntılı anlatılmaktadır. Şeytanın her va'dinin müşriklerin

\footnotetext{
45 Taberî, Câmi'u'l-Beyân VIII, 109-112; Mevdûdî, Tefh'imu'l-Kur'an, III, 123. Ayrıca, Zemahşerî. el-Keşşâf, II, 633634; Mâturîdî, Te'vîlâtu Ehli's-Sünne, III, 172-176; Meydânî, Meâricu't-Tefekkür, IX, 669-680.

46 Mâturîdî, Te'vîlâtu Ehli's-Sünne, III, 175; Râzî, Mefâtihu'l-Gayb. XXI, 7.

47 Râzî, Mefâtihu'l-Gayb. XXI, 9; Zemahşerî. el-Keşşâf, II, 634.

${ }^{48}$ Râzî, Mefâtihu'l-Gayb. XXI, 3-5.

${ }^{49}$ Râzî, Mefâtihu'l-Gayb. XXI, 10.

50 Mevdûdî, Tefhîmu'l-Kur'an, III, 123.

${ }^{51}$ Câbirî, Medhal, 296-297.
} 
hayatında gerçekleşmiş olması Allah'a inandıklarını iddia eden müşriklerin aslında zihnen ve davranış olarak şeytanın kontrolünde olduklarını göstermektedir.

"Âyette (inanan) kullarım üzerinde senin bir etki ve nüfuzun olmayacak" buyrulmas1 Hz. Peygamber ve sahabileri teskin etmekte, güçlendirmekte ve ilahi koruma karşısında şeytan ve avanesinin bir hiç olduklarını anlatmaktadır. Aynı zamanda Müslümanların kalbinde Allah velâyeti, Rabliği ve tevhid inancının tüm yönleriyle yerleşmesi ve ilahi korumayı da hayatlarında tecrübe etmeleri anlamına da gelmekteydi.

\section{Hicr Sûresi 26-44. Âyetler}

Hicr sûresinin 26-44. âyetlerde Hz. Âdem'in kissas1 anlatılmaktadır. Kıssada insanın kuru balçıktan, cinlerin ateşten yaratıldığı, Hz. Âdem'e şeytanın secde etmeyip, isyanından Yüce Allah'i sorumlu tuttuğu, kıyamete kadar mühlet istediği, şeytan ve hizbinin cehennemde olacakları gibi hususlar anlatılmaktadır.

Sûrenin daha önceki âyetlerinde yaratmanın Allah'a has olduğu açıklandıktan sonra şeytanın insanoğlunun düşmanı olduğu, insanların ona karşı uyanık, teyakkuzda bulunmalarının gerekliliğini beyan etmek için Hz. Âdem kıssası anlatıldı. Bir şeyin ilk defa yaratılması kudretin yüceliğini daha iyi anlattığı için ahireti inkâr eden müşriklere dirilişin imkânını izah etmek ve ders vermek için $\mathrm{Hz}$. Âdem’in yaratılışı açıklandı. Topraktan yaratılan insana Allah'ın ruhundan üflenmesinin beyan edilmesi meleklere en şerefli varlığın maddi terkibinden dolayı değil meziyetlerinden, ruh üflenmesinden dolayı üstün kılındığını açıklamaktadır. Kıssada şeytanın ancak dalâlet ehli ve yanlışa meyyal olanlar üzerinde tasallutunun olduğu ${ }^{52}$ ve müşriklerin liderleri ve taraftarlarının durumları açıklanmıştır. ${ }^{53}$

"Buraya kadar geçen âyetlerde (1-25) kâfirlerin kendilerini felakete sürükleyecek sapık yollara tabi oldukları söylenmişti. Bu kıssa müşriklere bazı hususları anlatmaktadır. 1 . Onlara uydukları yolun, en büyük düşmanları olan şeytanın saptırması olduğunu hatırlatmak için ele alınmıştır: "Sizi kandıran kıskançlık ve düşmanlığı nedeniyle sizi alçaklığın en kötüsüne yönelten şeytana tabi olmanın sonuçlarını düşünmemiz gerekir. Bunun tam tersine bizim peygamberimiz sizi sapıklıktan kurtarmak ve başarının yüceliklerine ulaştırmak için tüm gücüyle çalışıyor. Fakat ne yazık ki siz, düşmanınızı dost, dostunuzu da düşman olarak kabul ediyorsunuz.

2. Kurtuluşa ermenin bir tek yolu vardır. O da Allah'a itaat etmektir. Eğer bu yolu terk ederseniz, gittiğiniz tüm diğer yollar, sizi doğrudan cehenneme götürecek olan şeytanın yollarıdır. 3. Yaptığınız hatalardan kendiniz sorumlusunuz, şeytan değil. Çünkü onun

\footnotetext{
52 İbn Âşûr, et-Tahrîr, XIV, 41-54; Râzî, Mefâtîhu'l Gayb, XIX, 182-195.

${ }^{53}$ Habenneke, Meâricu't-Tefekkür, XI, 48-58: Taberî, Câmiu'l-Beyân, VII, 511-519. Taberi, 7: 515'de İbn Abbas'tan sırasıyla üç grup meleğin Adem'e secde emrini reddettikleri için helak edildiklerini, daha sonra yaratılanların secde emrini kabul ederek "işittik itaat ettik" dediklerini naklediyor.
} 
yapabileceği tek şey sizi Allah'a itaatten vazgeçirmeye çalışmak ve sizi kandırmaktır. Bu nedenle şeytanın aldatmalarına kapılıp kapılmama sorumluluğu size aittir."54

Sûrede müşriklerin $\mathrm{Hz}$. Peygamberden talepleri ile diğer toplumların peygamberlerinden taleplerinin örtüştüğü görülmektedir. Müşriklere göklerin kapıları açılsa ve yükseklere gitseler bile bunu da inkâr edeceklerinin açıklanması ${ }^{55}$ şeytanın inâdî inkârıyla ${ }^{56}$ benzeşmektedir. ${ }^{57}$

İnsanın çamurdan yaratılması bir yönüyle müşriklere "Topraktan, çamurdan yaratıldığınızı unutup, her şeyin sahibi olan Allah'a nasıl karşı çıkıyorsunuz?" mesajını da vermiş olabilir.

40. âyette şeytan'in muhlasin'e dokunamayacağını söylenmektedir. Muhlas Allah'in seçtiği, koruması altına aldığı, günahlardan koruduğu, kendine has kul seçtiği ve özel lütuflarda bulunduğu kişidir. ${ }^{58}$ Şeytan'ın bu ikrarı tevhide iman edip, sebat eden $\mathrm{Hz}$. Peygamber ve sahabilere dokunamayacağını, dolayısıyla ancak müşrikleri etkisi altına alacağını anlatıyor. Bu bilgi aynı zamanda Müslümanlara Allah'nn velisi ve koruma altında olduklarını anlattığı kadar müşriklere de şeytanın velisi olduklarını da anlatmaktaydı. ${ }^{59}$

Hicr sûresindeki âyetlerin genel muhataplarının müşrikler, daha özel de ise sahabiler olduğu anlaşılmaktadır. Bu âyetlerde dirilişin imkânı, şeytanın ilahi huzurdan kovulduğu için vahye zarar veremeyeceği, müşriklerin kibir ve gururlarıyla şeytanın yolundan gittikleri, kendilerinin mecnun, şair ve kâhin olarak niteledikleri, değersizleştirmeye çalıştıkları Hz. Peygamber ve sahabilerin Allah'in korumasında oldukları bunu da bizzat şeytanın kendisinin itiraf ettiği, şeytan ve hizbinin cehennemde toplanacakları, muttakilerin ise cennetlerde olacakları anlatılmaktadır. Şeytanın bu sözleri Hz. Peygamber ve sahabilerin korunmuşluğunu, hak yolda olduklarını anlatırken müşriklerin de şeytanın, batıl yolda olduklarını anlatmış olmaktaydı. Aslında bu âyetlerle Mekke'de siyasi açıdan güçlü olan müşrikler dini ve ilmi açıdan zayıflatılmış, dayanakları ellerinden alınmış; görünürde zayıf olan Müslümanlar ise güçlendirilmiş, onore edilmiş oluyorlardı.

\section{Kehf Sûresi 50-51. Âyetler}

Kehf Sûresinde müşriklere dünya hayatının fâniliği ve mahşerdeki zor durumları anlatıldıktan sonra 50-51. âyetlerde cinlerden olan şeytanın Hz. Âdem'e secde etmemesi, şeytan ve avanesini müşriklerin velî edindikleri, hâlbuki bunların ne kendilerinin ne de diğer varlıkların yaratılmasında bir şahitliklerinin olmadığı ve Allah Teâlâ'nın insanları dalâlete götüren bu varlıkları kendisine yardımcı edinmediği anlatılmaktadır. Daha sonraki âyetlerde de mahşer günü müşriklerin yardım çağrısına ilahların karşılık veremeyeceği açıklanmaktadır.

\footnotetext{
54 Mevdûdî, Tefhîmu’l-Kur'ân, II, 573.

55 Hicr, 14-15.

${ }^{56} \mathrm{Hicr}, 26-28$.

57 Câbirî, Medhal, 297-298.

58 Mâturî̀î, Te'vîlâtu Ehli's-Sünne, III, 51

${ }^{59}$ Râzî, Mefâtîhu'l-Gayb, XIX, 194.
} 
“İblîs ve şeytanlar insanlar için düşmandır. Müşrikler Allah’ı bırakıp da ona tapmakla çok büyük yanlış yapmakta, gerçek ilahı bırakıp sahte ilaha tapmaktadırlar. İblîs ve zürriyetini Allah Teâlâ hiçbir konuda yardımcı, destek edinmemiştir."60 "Şeytanın yardımcıları vardır. Allah Teâlâ bunlarla varlıkların yaratılmasını istişare etmemiş, müşriklerin yaratılmasına şahit de tutmamıştır. Bu şekilde hiçbir değerleri, yetkileri olmayan varlıkları müşrikler nasıl velî ediniyorlar? Bunların dünyada bir faydası olmadığı gibi ahirette de faydaları, yardımları olmayacaktır."61 "Bu âyetlerden önce müssriklerin kibirleri, evlat ve mallarıyla övünmeleri, fakirleri dışlamaları, onlarla birlikte oturmamaları, Hz. Peygamber'den de onları yanından kovmasını istemelerine dair âyetler geçmişti.62 Burada da şeytanın kibri anlatılmaktadır. Müşriklerin ona itaatleri, yardımcı, ilah edinmeleri eleştirilerek 'Düşmanınızı nasıl veli, ilah ediniyorsunuz' denildi. İnsanları haktan uzaklaştıran şeytan ve avanesinin Allah'ın yardımcıları olmasının, ahirette de müşriklere yardım etmesinin mümkün olmadığı anlatılmaktadır.”63

"Meleklerin tersine cinler, insanlar gibi irade sahibi oldukları için itaat etme ve etmeme seçeneklerine sahiptirler. Yani onlara da inanma veya inanmama, itaat etme veya isyan etme özgürlük ve yetkisi verilmiştir. Bu, iblis’in cinlerden biri olduğu ve bu nedenle de isyan yolunu seçtiği söylenerek açıklanmıştır. Bu âyet iblîsin bir melek olduğu, hatta meleklerin başkanı olduğu yönündeki görüşleri ortada kaldırmaktadır. 51. âyette kâfirlere kendileri de yaratılan varlıklardan olan, yerlerin ve göklerin yaratılışında hiçbir katkıları olmayan şeytanların itaat ve ibadete layık olmadıkları, sadece Allah'ın ibadete layık olduğu anlatılmak istenmiştir.”64

Âyetlerin bağlamından muhatapların Mekkeli müşrikler oldukları anlaşılmaktadır. Müşrikler şeytanı, cinleri ilahlaştırıyorlardı. Bu âyetlerde de şeytan ve cinlerin ilah olmadıkları, tam tersine Allah'a isyan eden varlıklar olduğu, ne dünyada ne de ahirette müşriklere yardım edemeyecekleri anlatılmaktadır. Bu sûre bağlamında Hz. Âdem-İblîs kıssası şirk inancının, Allah’tan başka varlıkları ilahlaştırmanın yanlışlığı, tutarsızlığı beyan edilmiştir.

\section{B. Medenî Surelerde Hz. Âdem-İblis Kıssası \\ 1. Bakara Sûresi 30-39. Âyetler}

Bakara Sûresinde Yahudilere, münafiklara ve kâfirlere yönelik pek çok eleştiri, uyarı yapıldıktan sonra 30-39. âyetlerde Hz. Âdem-İblîs kıssası anlatılmaktadır. Burada Hz. Âdem’in halife kılınması, meleklerin itirazı/sorusu, Hz. Âdem'e isimlerin öğretilmesi, İblîs’in secde etmemesi, Hz. Âdem ve Havvâ'yı kandırması gibi hususlar anlatılmaktadır. Kıssa sonrasındaki âyetlerde de İsrailoğulları eleştirilmektedirler.

\footnotetext{
60 Mukâtil, Tefsîr, I, 292.

${ }^{61}$ Kurtûbî, el-Câmi‘u li Ahkâmi'l-Kur'ân, XIII, 300-306; Derveze, et-Tefsîru'l-Hadîs, V, 75.

Meydânî, Meâricu't-Tefekkür, XIII, 776.

${ }^{62} \mathrm{Kehf}, 18 / 28-48$.

${ }^{63}$ Ebu Hayyan, el-Bahru'l-Muhît, VI, 128-130; el-Maturîdî, Te'vîlâtu Ehli's-Sünne, III, 237-238.

${ }^{64}$ Mevdûdî, Tefhîmu'l-Kur'an, III, 176.
} 
Bakara Sûresinde Mekkî surelerde hiç değinilmeyen Hz. Âdem’in halife kılınması ve buna meleklerin tepkisi öne çıkmaktadır. Kıssadaki konu değişimi bağlam, muhatap ve mesajının da diğer sûrelerden farklı olduğunu düşündürmektedir.

Kıssanın bağlamıyla ilgili Taberî (ö. 310/923 )şunları kaydetmektedir: Buraya kadar olan âyetlerde Allah Teâlâ muhataplarını kendilerine ve atalarına bahşettiği yardımları ve nimetleri anlattı. 29. âyet ile sûrenin 6. âyetinden itibaren bahsedilen münafiklar ve velileri Yahudilerin ahbârını günaha saplandıkları, isyan ettikleri için cezalandırmakla tehdit etti. Ataları ma'siyete daldıkları için nasıl verilen nimetler geri alındı ve cezaya çarptırılmışlarsa, Medineli Yahudilere de bir an önce tövbe etmeleri gerektiği yoksa aynı akıbete uğrayacakları anlatıld1. Bundan sonra da insanlığın atası olan Hz. Âdem'e verilen nimetler, şeytanın ona düşmanlığı, kandırması, Hz. Âdem'in tövbesi, şeytanın kibri, inkârı, lanete uğraması konuları Yahudilerin tövbe etmesi, akıllarını başlarına almaları için anlatıldı. Bu âyetlerin asıl muhatapları bu kıssaları bilen Yahudiler olmakla birlikte bu kıssaları bilmeyen ümmî müşrikler de âyetlerin muhatabıdır. Yahudilerin bildiği, Arapların bilmediği kıssalar Yahudilerden herhangi bir eğitim almayan Hz. Peygamber'e vahiy yoluyla öğretilerek onun gerçekten peygamber, anlattıklarının da vahiy olduğu, İsrailoğullarının tarihlerinin, gizli bilgilerinin de vahyedildiği muhataplara ispatlanmak istenmiştir.65 Allah'in hükümlerini uygulama konusunda yeryüzünde halife olarak yaratılan Hz. Âdem'in kıssası insanoğluna verilen değeri anlatmak için vahyedildi.66 "Buraya kadar geçen âyetlerde insandan yaratan, hayatı ve ölümü takdir eden Allah'a itaat etmesi isteniyordu. Bu âyetlerde ise insan, yeryüzünde halifesi olduğu Allah'a itaat etmeye davet ediliyor. Bu nedenle insan, Allah'a itaat etmesi, hidâyetine tabi olması ve sürekli kendisini saptırmak için fırsat kollayan şeytana uymaması konularında uyarıliyor. ${ }^{67}$

İbn Âşûr'a göre Tevrat'in Tekvin bölümünde geçen Hz. Âdem-İblîs kıssas1, Araplara karşı ilim sahibi olmakla övünen Yahudilere bu kıssayı Müslümanların da bildiğini, onların da ilim sahibi olduklarını göstermek için anlatılmıştır. 68

"Âyetlerde şeytanın yüz çevirmesi, kibri ve inkârı anlatılarak Hz. Peygamber'in ve sıfatlarını bilen, geleceğini müjdeleyen ancak hasetlerinden dolayı inkâr eden mütekebbir Yahudiler ve âlimleri kınanmaktadır. İblîs kâfirlerden sayılarak aslında insan olmadığı halde inkarcı Yahudilerle aynı cinsten sayıldı. Bundan dolayı kâfirlerle İblîs arasında başka yönden bir benzerlik, mücaneset gözetmek lüzümsuzdur. ${ }^{69}$ "Kıssadan da anlaşıldığ1 gibi ilk günahlar kibir ve hasettir. Şeytan bilerek, inadına Allah'a itaat etmediği için küfre girmiştir."70

\footnotetext{
65 Taberi, Câmiu'l-Beyân, I, 226-227.

66 Taberi, Câmiu'l-Beyân, I, 233-234.

67 Mevdûdî, Tefhîmu'l-Kur'an, I, 61.

68 İbn Âsûr, et-Tahrîr, I, 396.

69 Elmall1, Hak Dini Kur'an Dili, I, 274-275.

${ }^{70}$ Kurtubî, el-Câmi‘u li Ahkâmi'l-Kur'ân, I, 442- 444.
} 
“Kıssada Hz. Âdem'e halifeliğin verilmesi, insanın meleklerden üstün kılınması, Hz. Âdem'in tövbesi ve şeytanın şahsında temsil edilen kötü, kargaşa çıkartıcı, yıkıcı güçler anlatılmıştır. Bundan sonraki âyetlerde Medine'de Hz. Peygamber ve Müslümanlara sorun çıkaran İsrailoğulları ile hesaplaşma konusuna geçildi. Bu konu işlenirken Yahudiler Yüce Allah ile aralarındaki ahde uymamaları, kendilerine sunulan nimetler, Yahudilerin nankörlükleri ve bunun sonucunda da halifelik görevinden uzaklaştırılmaları ve perişanlığa mahkum edilmeleri hatırlatıldıktan sonra mü'minler gerek onların entrikaları ve gerekse tökezlemeleri konusunda uyarılmışlardır. Görülüyor ki burada Hz. Âdem'in halifelikle gönderilişi kıssası ile İsrailoğulları'nın bu göreve getirilişi kıssası arasında yakın bir ilişki kuruluyor. Gerek olayların akışında ve gerekse anlatım biçiminde sıkı bir uyum bulunmaktadır. ${ }^{71}$

Hz. Peygamber'in risaleti öncesinde Yahudiler son peygamberin gelmesini bekliyorlar ve bu peygamberin de kendilerinden olmasını ümit ediyorlard1. Ancak son peygamber Araplardan seçilince Allah'ın elçiliğinin, temsilciliğinin/halifeliğinin kendilerinden alınıp küçümsedikleri Araplara verilmesinden Yahudilerin geneli Hz. Peygamber' inkâr ederek düşmanlık yaptılar. Kıssanın bu sûredeki bölümünde şeytan Yahudileri temsil etmekte ve onlara "Haset, kibir ve gururunuzdan dolayı şeytanın yolundan gidiyorsunuz" denilmektedir.

Hz. Âdem'in halife kılınmasına meleklerin "Fesat çıkaracak, kan dökecek bir varlığı mı halife kılacaksın?" şeklindeki soru, itirazıyla ilgili müfessirler pek çok konuyu tartışmışlardır. Burada bu konulara sadece makalede ele alınan hususlarla ilgili olduğu nispette konulara yer verilecektir.

"Meleklerin halifenin zürriyetine ifsat ve kan akıtmayı izafe ederek "Seni tesbih ve takdis eden bizi birakıp da kan dökme ve ifsat etme sıfatlar, özellikleri olan birini mi halife yapacaksın" demeleri bir sorudur. Yoksa herhangi bir inkâr söz konusu değildir. Taaaccüb ettiklerine dair âyetlerin zahirinde herhangi bir işaret bulunmamaktadır."72 Meleklerin konumu evladının tufanda boğulmamasını isteyen $\mathrm{Hz}$. Nuh'un itab edilmesine ve tövbe etmesine ${ }^{73}$ benzemektedir. Melekler de benzer şekilde "Rabbimiz sen yüceler yücesisin. Biz senin öğrettiğinden başka hiçbir bilgiye sahip değiliz" şeklinde istiğfar ederek cevap verdiler. $\mathrm{Bu}$ âyetlerle kâhin ve müneccimler ile azgınlık ve dalâlette 1srar eden Ehl-i kitab kınanmış, iblîsin akıbetine uğramamaları için uyarılmıştır. ${ }^{74}$

\footnotetext{
${ }^{71}$ Kutub, Fì Zilâli'l-Kur'an, I, 91-92.

72 Taberî, Câmiu'l-Beyân, I, 235-246.

${ }^{73}$ Nûh, Rabbine seslenip şöyle dedi: "Rabbim! Şüphesiz oğlum da âilemdendir. Senin va'din elbette gerçektir. Sen de hükmedenlerin en iyi hükmedenisin.” Allah, "Ey Nûh! O, asla senin âilenden değildir. Onun yaptığı, iyi olmayan bir iștir. O hâlde, hakkında hiçbir bilgin olmayan șeyi benden isteme. Ben, sana cahillerden olmamanı öğütlerim" dedi. Nûh, "Rabbim! Şüphesiz ben senden hakkında bilgim olmayan şeyi istemekten sana sığınırım. Eğer beni bağışlamaz ve bana acımazsan, şüphesiz ziyana uğrayanlardan olurum" dedi. Nûh, "Rabbim! Şüphesiz ben senden hakkında bilgim olmayan şeyi istemekten sana sığınırım. Eğer beni bağışlamaz ve bana acımazsan, şüphesiz ziyana uğrayanlardan olurum" dedi. Hûd Sûresi, 11/45-47.

74 Taberî, Câmiu'l-Beyân, I, 256, 258.
} 
Zemahşerî̀ye (ö. 538/1144) göre ise melekler kendi yerlerine günah işleyecek insanı halife tayinine taaccüb ederek "Bu makam biz tesbih ve takdis ehli daha layıkı" demişlerdir. ${ }^{75}$ İbn Kesir'e göre ise meleklerin bu soruları Allah'n hikmetini anlamaya yöneliktir. Bazılarının iddia ettiği gibi itiraz ve haset söz konusu değildir.76 "Halifeden maksat 1slah ve ifsadı terk etmektir. Fakat melekler Âdem'deki ifsad yönünü görünce bunu umumileştirdiler. Allah Teâlâ da insanlardan ifsat edenin de etmeyenin de olacağını açıkladı. Onların kalplerini rahatlatmak için "ben en iyi bilirim" buyurdu."77

Kurtubî (ö. 671/1273), "Eğer melekler en üstün varlık oldukları halde Âdem'e secde emrinin hikmeti nedir" denilirse "Melekler kendi tesbih ve takdislerini büyük görünce Allah onlara kendisinden başkasına secdeyi emrederek onların ibadetlerine ihtiyacının olmadığını gösterdi' şeklinde cevap verilir" demektedir. Ayrıca bazı âlimlere göre de melekler Âdem’i ayıplayıp, kınayıp küçük gördükleri, ondaki üstün özellikleri göremedikleri için tazim secdesi emredilmiştir. "Kan dökecek birini mi.." demelerinden dolayı onlara bir ceza, yaptırım olarak secde emredilmiş olması da ihtimal dahilindedir. ${ }^{78}$

İbn Âşûr'a göre "Meleklere Âdem’in tanıtılması insan cinsine karşı kalplerindeki su-i zannı izale, bir tür istişare ve gözden kaçırdıkları hikmetleri idrak etmeleri içindir. Melekler Âdem'in halife kılınmasına taaccüp etmişler, halife tayinini isabetli görmemişler, onun olumsuz yönüne bakarak 'O, dünyayı imar edemez, biz daha iyiyiz' demişlerdi. Allah Teâlâ'nın "Ben daha iyi bilirim.' şeklindeki cevabı 'Ben beşerin salah ve fesat özelliklerini daha iyi bilirim' anlamındadır."79

Naklettiğimiz yorumlardan müfessirlerin meleklerin sorusunu farklı değerlendirdikleri görülmektedir. Meleklerin masumiyetini öne çıkaran ve bu soruyu bir isyan gibi değerlendiren âlimler genellikle onların normal bir soru sorduklarını, Allah'ın hikmetini anlamaya çalıştıklarını belirtirken, konuyu masumlukla sınırlandırmadan, daha genel çerçevede alanlar ise meleklerin $\mathrm{Hz}$. Âdem ve nesline halifelik verilmesine taaccüp ettikleri, kıskandıkları ve itiraz ettikleri temelinde ele aldıkları görülmektedir. Âyetlerin zahirinden ve tefsirlerdeki rivâyet ve görüşlerin genelinden ikinci yaklaşımın daha isabetli olduğu anlaşılmaktadır. Meleklerin bu tavırlarını isyan gibi değerlendirmediğimizde konu daha rahat anlaşılmaktadır.

Meleklerin tepkileri Medineli Yahudilerin tepkileriyle benzeşmektedir. Onlar da kendilerini üstün gördükleri için "Ümmî Araplardan birinin peygamberliğe layık olmadığını, Allah Teâlâ'nın bu takdirinin çok da isabetli olmadığını iddia etmişlerdi." Bu âyetlerde anlatıldığ gibi $\mathrm{Hz}$. Âdem'e isimlerin öğretilerek, kendilerinin bilmediği ilmin verilmesiyle Âdem’in üstünlüğünü, Allah'ın halife tayinin hikmete mebni olduğunu anladıklarında da Melekler görüşlerinin hatalı olduğunu anlayarak secde emrini de yerine getirmişlerdi. Hz.

\footnotetext{
${ }^{75}$ Zemahşerî, el-Keşşâf, I, 154.155

76 İbn Kesîr, Tefsîru'l-Kur'âni'l-'Azîm. I, 337. Ayrıca bk. Kurtubî, el-Câmi'u li Ahkâmi’l-Kur'ân, I, $391-489$.

77 Kurtubî, el-Câmi'ul i Ahkâmi'l-Kur'ân, I, 409.

78 Kurtubî, el-Câmi'u li Ahkâmi'l-Kur'ân, I, 435-436.

79 İbn Âşûr, et-Tahrîr, I, 400-427.
} 
Peygamber Yahudilere başkasını bilmediği konuları vahiy yoluyla anlattığında da onlar $\mathrm{Hz}$. Peygamber'in risaletinin hak olduğunu anlamalarına karşı1ık küçük bir azınlık dışında melekler gibi kendilerini toparlamadilar. Hz. Peygamber'e iman etmediler. Şeytan gibi haset, inat ve kibre kapılarak kâfirliği tercih ettiler. Kıssanın bu sûredeki bölümünün Medine'nin ortamı ile tam olarak örtüştüğü görülmektedir. Bu da Kur'an'in tedrîcen nüzûlünün bilinmesinin, Kur'an'ı anlamda sîretin ve rivâyetlerin önemini göstermektedir.

Kıssayı daha farklı bir açıdan değerlendiren M. Abduh'a (1849-1905) göre Allah Teâlâ ile melekler arasındaki konuşmaların anlatılmasının bir hikmeti de insanların yalanlamaları ve delilsiz inkârları karşında darlanan Hz. Peygamberin teselli edilmesidir. Allah Teâlâ'nın mukarrab meleklerinin soruları karşısında onları mazur görerek delillerle irşad etmesi gibi Peygamber'e en yakışan tavır da yalanlara sabretmesi, doğruyu öğrenmek isteyenleri irşat etmesi ve en açık delilleri sunmasıdır. Bu izah kıssasının öncesindeki âyetlerle bağlantısını açıklamaktadır. Ayrıca insanın tabiatında bilmediği şeyi inkâr etme davranışı olduğundan dolayı kıssa ile insanların bu tür yanlışlarından tövbe etmeleri için ilim yolula ikna edilmesi gerektiği açıklanmaktadır. ${ }^{80}$ "Hz. Âdem-İblîs kıssası ile Hz. Peygamber'e günah işlemenin insanın tabiatından kaynaklandığı, Hz. Âdem'in de vesveselerin etkisiyle günah işlediği, dolayısıyla inkârcıların sözlerine üzülmemesi ve bu tavırlarından dolayı kendini germemesi gerektiğini anlatılmaktadır. ${ }^{81}$

Taberî̀nin ifadesi ile İblîsin kibri ve inkârı ile muhacirlerle birlikte yaşayan Yahudilerin ve ahbârın bilerek inkârları, haset ve azgınlıkları aynıdır. Bunlar Hz. Peygamber'i tüm delillere rağmen inkâr ettikleri için kâfirlerden sayılmıştır. Sûrede Hz. Âdemin tövbesini Yahudiler dâhil bütün muhataplara örnek gösterilmiştir. ${ }^{82}$

Âyetlerin bağlamından ve naklettiğimiz bilgilerden kıssanın bu sûredeki asıl muhataplarının Yahudiler olduğu anlaşılmaktadır. Yahudilere Hz. Peygamber’in risaletine meleklerin Hz. Âdem'in halife kılınmasına benzer tepkiler verdikleri, ancak ortaya konan bütün gerçeklere rağmen inatlarından vazgeçmeyerek meleklerin yolundan ayrıldıkları, kibir ve hasetleriyle şeytanın izinden gittikleri her ne kadar kendilerini seçilmiş, üstün millet olarak görseler de aslında dolayısıyla şeytanın yolunda oldukları anlatılmıştır. Meleklerin secdesi ile onları ilahlaştıran müşriklere "ilah kabul ettiğiniz varlıklar Allah'ın Âdem'e/rasulüne secde emrini yerine getirdiler, siz ise gönderilen peygamber'i inkâr edip şirk koşarak ilahlaştırdığınız meleklerin yolundan ayrılıyor, düşman kabul ettiğiniz şeytanın yoluna tabi oluyorsunuz" mesajı da verilmiştir.

\section{Sonuç}

Müfessirler âyetler arası ilişki ve uyumu münâsebâtu'l-Kur'ân başlığı altında mushaf tertibi temelinde açıklamaktadırlar. Bu tertibe göre âyetler ve sûreler arası tenasüp

\footnotetext{
80 Muhammed Abduh-Reşid Riza. Tefsîru'l-Menâr, (Misır: Dâru'l-Menâr, 1366/1947),I, 255-257. Ahmed Mustafa elMerağî, Tefsîru'l-Merâğî̀, (Misır: Mektebetu ve Matbaatu Mustafa el-Bâbî el Halebî ve evlâduhû, 1365/1946), I, 76.

${ }^{81}$ Merağ̂̀, Tefsîru'l-Merầ̆

82 Taberî, Câmiu'-Beyân, I, 265-266; 283.
} 
bulunmakta ve bu konudaki açıklamalar büyük öneme sahip olmakla birlikte âyetler nüzûl sürecinde sîretle birlikte değerlendirildiğinde Kur'an'in asıl tenâsübünün mushaf tertibinde değil vahyedildiği ortam ve şartlarla ilgili olduğu, mesajlarının doğrudan muhatapların hayatlarıyla birebir örtüştüğü, karş1lık bulduğu anlaşılmaktadır. Birbiriyle alakasız gibi duran veya bazen "Bu konu Kur'an'da niçin anlatıyor" şeklinde farklı sorulara da sebep olan konuların Hz. Peygamber ve Müslümanların hayatlarıyla ne kadar bağlantılı ve hayati öneme sahip olduğu fark edildiğinde Kur'an'in ne kadar hikmetli, doğru zamanda en uygun üslupta konuları anlattığı, gündeme getirdiği anlaşılmaktadır. Yaşadığımız şartlar, zihni hazır bulunmuşluk ve tartışmalar üzerinden anlamakta zorlandiğımız, kapalılıklar bulunduğunu düşündüğümüz âyetler bu yöntemle daha anlaş1lır hale gelmektedir. Bu yönüyle birçok âyette zikredilen ve doğrudan muhataplarca tartışma, inkâr, eleştiri konusu yapılmayan "kitâbun mübîn"83 tanımlamasının da ilk muhataplar için ne kadar yerinde olduğu anlaşılmaktadır.

Çalışmada kaynak olarak istifade ettiğimiz Taberî, Elmalılı, İbn Âşûr, Mevdûdî ve Derveze gibi müfessirlerin Hz. Âdem kıssasını diğer müfessirlere nispetle nüzul sürecini göz önüne alarak değerlendirdikleri için yorumlarının Kur'an'ın bütünlüğüne, konu gelişimine, nüzul-sîret ilişkisine/bütünlüğüne daha mutabık olduğu görülmektedir. Aslında nüzul-siret bütünlüğünde ne anlattığı ve hangi muhataplara ne mesajlar verdiği çok açık olan âyetler tefsir tarihindeki tartışmalarla karışık hale gelebilmekte, hatta bazen ilk anlamın ne olduğu bile hiç düşünülmemektedir.

Hz. Âdem-iblîs kıssasını Hz. Peygamber ve sahabenin tecrübeleri eşliğinde okuduğumuzda Mekkî sûrelerde müşriklerin isyanı, inkârı, kibirleri ve hasetleri ile şeytanın karakteri ve tavrının özdeşleştirildiği görülmektedir. Aynı şekilde A'raf sûresindeki âyetler örneğinde olduğu gibi Allah'a inandıklarını söyleyen müşriklere şeytanın yolundan gittikleri, onun velisi oldukları açıklanarak hakikat karşındaki yerleri açıklanmıştır. Bu açıklama ile önemli olanın kendi kendilerini tanımlarının değil Allah Teâlâ'nın nazarındaki tanımlarının ne olduğu, asıl bunun önemli olduğu beyan edilmiştir. Bu açıklamalarla Mekkelilerin sapkınlıkla suçladıkları Hz. Peygamber ve mü'minlerin Allah'ın dostları olarak hak üzere oldukları da açıklanmıştır. Müşriklerce ilahlaştırılan meleklerin Hz. Âdem'e secdelerinin anlatılması bütün varlıkların Allah'n kulu oldukları, O'ndan izinsiz bir şey yapmalarının mümkün olmadığını dolayısıyla Mekkelilerin melek ve ilah tasavvurlarının yanlış olduğu açıklanmıştır. Kıssa ile ilgili âyetlerde şeytan ve cinlerin herhangi bir ilahlıklarının, müşriklere yardımlarının söz konusu olmadığı da anlatılmıştır. Ayrıca Hz. Âdem gibi kendine vahiy, bilgi verilen ve Allah'in halifesi, temsilcisi olan Hz. Peygamber'in meleklerden ve şeytandan üstün olduğu, ona iman ve itaat edilmesi gerektiği de beyan edilmiştir. Kıssa ile şeytanın ve ona tabi olanların batıl yolda oldukları anlatıldığı kadar şirkin hâkim olduğu Mekke'de şirk düşüncesinin temelleri sarsılırken adım adım kelime-i tevhidin inşası da gerçekleştirilmiştir.

\footnotetext{
83 Yûsuf, 12/1; Hicr, 15/1; Şuarâ, 26/2.
} 
Tâhâ Sûresi 115-123. âyetlerde diğer mesajlarla birlikte Hz. Peygamber'e İslam'1 yaşama ve tebliğ konusunda sebat ve azim sahibi olması gerektiği, Hz. Âdem gibi sebatsızlık göstererek şeytana, nefsine uymaması gerektiği anlatılmıştır.

Bakara Sûresinde ise özellikle İslam'a düşmanlık yapan Yahudi liderler ve din adamları haset, kibir, inkâr ve inatta şeytana benzetilmiştir. İsrailoğullarına $\mathrm{Hz}$. Peygamber'e risâlet görevinin verilmesiyle artık Yahudilerin değil $\mathrm{Hz}$. Peygamber ve sahabenin ilahi emaneti yüklenen Allah'ın halifeleri ve seçkin kulları oldukları anlatılmıştır. Bütün bu açıklamalar âyetlerin anlaşılmasında bir tek bakış açısının ve tefsir metodunun yeterli olmadığını da göstermektedir. Kur'an'ın anlam zenginliği ve boyutlarının ancak farklı usullerle yapılacak bütüncül okuma tarzıyla ortaya konulabildiği anlaşılmaktadır.

Mekke ve Medine'de kendilerini hakikat üzere gören müşrik ve Yahudilere yollarının ve karakterlerinin şeytanın yolu olduğunu açıklamak bir yönüyle ortamın gerilmesi ve muhaliflere gereken dersin verilmesi anlamına geldiği gibi diğer taraftan sahabeye seçilmiş, özel ve sevilen taraf olduklarının beyanı olduğu için moral motivasyon olmaktaydı. Âyetlerde şeytanın Allah'in ihlaslı kullarına zarar veremeyeceğinin beyanı Müslümanlara ilahî koruma ve destek altındaki has kullar olduklarını, zor şartlara rağmen ümitsizliğe ve yılgınlığa düşmemeleri gerektiğini de öğretmekteydi. Bu âyetlerin Mekke ve Medine gibi zor şartlar da muhaliflere tebliğ edilmesi ise $\mathrm{Hz}$. Peygamber ve sahabenin görevlerinin ağırlığını da göstermektedir.

Hz. Âdem-şeytan kıssasında anlatılanlar Hz. Peygamber'den çok önce yaşanan olaylardır. Ancak kıssadan nakledilen konuşmalar ve olaylar Mekke ve Medine'de yaşananlarla İslam muhalifleriyle yapılan mücadeleyle tam olarak örtüşmektedir. $\mathrm{Bu}$ örtüşme genel itibarıla aslında her bir insanın ve büyük ölçekte Müslüman toplumun farklı zaman ve ortamlarda şeytanla ve hakikat karşıtlarıyla imtihan edilme ve onlarla mücadele yaşadığı durumlarını da anlatmaktadır. Bu da Kur'an'ın mesajının sürekliliğini ve kuşatıcılığını da göstermektedir.

Çalışmaya konu olan bu kıssa örneğinde de görüldüğü üzere Kur'an'ı en iyi anlama yolunun nüzûl sürecini dikkate alarak sîret eşliğinde okuma ve yorumlama olduğu anlaşılmaktadır. Bu usûl ile soru ve soruna dönüşen birçok konu da en kısa yoldan çözümlenmiş olmaktadır.

\section{Kaynaklar}

Abduh Muhammed - Riza Reşid. Tefsîru'l-Menâr. Misır: Dâru'l-Menâr, 1366/1947.

Aldemir, Halil. "Vahiy Öncesi Kur'an Kıssalarının Bilinebilirliği" Din Bilimleri Akademik Araştırma Dergisi, 11 (1), 165-218. 
Ay, Mahmut. "Kur'an Kissalarını Hz. Muhammed'in (sav) Kissası Paralelinde Okumak", Kur'an Nüzûlünün Medine Dönemi Sempozyumu, X. Tefsir Akademisyenleri Buluşması Sempozyum Bildirileri, (Kahramanmaraş, 17-19 Mayıs 2013), 126-142.

Burhan, Çonkor, "Kronolojik Sûre Tertibi Çalışmalarına Etkisi Bağlamında İhtilafa Sebep Olan Nüzûl Rivâyetleri Üzerine Bir Değerlendirme”. Mütefekkir, 5 (9), 47-64.

Câbirî, M. Âbid. Medhal ile'l-Kur'âni'l-Kerîm. Beyrût, Merkezu dirâsâti'l-Vahdeti'l-Arabî, 2007.

Ebû Hayyân, Muhammed b. Yusuf. el-Bahru'l-Muhît. thk. Âdil Ahmed Abdulmansur v.dğr. Beyrut: Dâru'l-Kütübi'l-İlmiyye, 1413/1993.

Mâverdî, Ebu'l-Hasen Alî b. Muhammed b. Habîb el-Basrî. en-Nüket ve’l-Uyûn. thk. esSeyyid b. Abdulmansur b. Abdurrahman, I-VI, Beyrut: Dâru'l-Kütübi'l-İlmiyyeMüessesetu'l-Kütübi's-Sekafi, ts.

el-Merağî, Ahmed Mustafa. Tefsîru'l-Merâğî. Mısır: Mektebetu ve Matbaatu Mustafa el-Bâbî el Halebî ve evlâduhû, 1365/1946.

Cerrahoğlu, İsmail. "Abdullah b. Mes'ûd”, DİA, İstanbul: Türkiye Diyanet Vakfı Yayınları, 1988.

Derveze, İzzet et-Tefsîru'l-Hadîs. Tunus: Dâru'l-Garbi'l-İslâmî, 1421/2008,

Derveze, İzzet. Kur'anü'l-Mecîd. trc. Vahdettin İnce. İstanbul: Ekin Yayınları, 1997.

Doğan, İshak. "Nüzûl Ortam1-Sûre-Kıssa İlisskisi (Kalem Sûresi Örneği), Din ve Bilim - Muş Alparslan Üniversitesi İslami İlimler Fakültesi Dergisi, 2 (1), 115-139.

Elmalıı M. Hamdi Yazır. Hak Dini Kur'an Dili. I-X, İstanbul: Yenda Yayın-Dağıtım, 2000.

İbn 'Âdil, Ebû Hafs Ömer b. Ali. el-Lubâb fî 'Ulûmu'l-Kitâb. thk. Adil Ahmet Abdulmevcûd ve diğerleri. I-XX, Beyrut: Dâru'1-Kütübi'l-İlmiyye, 1419/1998.

İbnü'l-Cevzî, Ebü'l-Ferec Cemâlüddîn Abdurrahmân b. Alî. Zâdü'l-Mesîr fî̀ 'ílmi't-Tefsîr. thk. Abdurrezzak el-Mecdî, I-IV, Beyrut: Dâru'l-Kütübi'l-Arabî, 1431/2010.

İbn Kesîr, Ebu'l-Fidâ İsmâil. Tefsîru'l-Kur'ani'l-'Azîm. thk. Mustafa es-Seyyid v. dğr. I-XV, Kahire: Müessesetu Kurtuba, 1421/2000.

İbn Âşûr, Muhammed b. Tâhir. Tefsiru't-Tahrîr ve't-Tenvîr. I-XXX, Tunus: Dâru Sahnûnli'nNeşrve't-Tevzi', 1984.

Kurtûbî, Abdullah b. Muhammed b. Ahmed. el-Câmi'uli Ahkâmi'l-Kur'ân. thk. Abdullah b. Abdu'l-Hasen et-Türkî. I-XXIV, Beyrut: Müessetu'r-Risale, 1427/2006.

Kutup, Seyyid. Fî Zilâli'l-Kur'an. çev. Komisyon, I-X, İstanbul: Dünya Yayınc1lık, 1989.

Maturîdî, Ebû Mansûr. Te'vîlâtu Ehli's-Sünne. Thk. Mecdî Bâsellûm. I-X, Beyrut: Dâru'lKütübi'l-İlmiyye, 2005.

Mevdûdî, Ebu'l-A'lâ. Tefhimu'l-Kur'an. Trc. Muhammed Han Kayanî v.dğr. 2. Baskı. I-VII, İstanbul: İnsan Yayınları, 1991.

el-Meydânî, Abdurrahman Habenneke. Meâricu't-Tefekküri ve Dekâiku't-Tedebburi. Dâru'1Kalem, Dimaşk, 1423/2002.

Mukâtil, Ebu'l-Hasen b. Süleyman. Tefsîru Mukâtil b. Süleyman. thk. Ahmed Ferid. Beyrut: Dâru'l-Kütübi'l-i̇lmiyye, 1424/2003. 
Öztürk, Mustafa. Kur’an Kissalarinin Mahiyeti. İstanbul: Kuramer Yay. 2016.

Râzî, Fahruddîn İbn Ziyâuddîn b. Ömer Muhammed. Mefâtihu'l-Gayb. I-XXXII, Beyrut: Dâru'l-Fikr, 1401/1981.

Suyûtî, Celaleddin Abdurrahman. el-ítkan fi Ulumi'l-Kur'an. thk. Ahmed b. Ali, I-II, Kahire: Daru'l-Hadis, 2006.

Şâtıbî, Ebu İshak. el-Muvâfakât. çev. Mehmed Erdoğan, İstanbul: İz Yayıncılık, 1999.

Şimşek, M. Sait. Kur'an'ın Ana Konuları. İstanbul: Beyan Yay. 2001.

Taberî, Ebû Ca'fer Muhammed b. Cerîr. Câmiu'l-beyân 'an Te'vîli Âyi'l-Kur'an. thk. Abdullah b. Abdulmuhsin et-Türkî. Beyrut: Dâru'l-Kütübi'l-İlmiyye, 2005.

Vâhidî, Ebu'l-Hasen Ali b. Ahmed. el-Vasît fî Tefsîri'l-Kur'âni'l-Mecîd. thk. Adil Ahmet Abdulmevcûd v.d., I-III, Beyrut: Dâru'l-Kütübi'l-İlmiyye, 1415/1994.

Zerkeşî, Bedreddin Muhammed b. Abdullah. el-Burhân fí Uulumi'l-Kur'an. thk. Mustafa Abdulkadir Atâ. I-IV, Beyrut: Dâru'l-Kütübi'l-İlmiyye, 1428/2007. 


\title{
READING THE ANECDOTE OF HZ. ÂDEM-IBLÎS IN THE CONTEXT OF REVELATION-PERSONALITY
}

\begin{abstract}
Many methods are applied and discussed regarding the understanding and interpretation of the Quran, which introduces itself as a source of guidance and distinction between good and bad. How to understand the anecdotes that comprise a great deal of the Quran are also discussed. Anecdotes are generally tried to be understood by bringing together the parts described in different chapters and constructing a new text

Since the Holy Quran is a wise book, it tells the subjects to the addressees at the most appropriate time with the right style. However, it may be difficult to discover the wisdom of some verses and issues. The Quran is a set of messages that are also guides to the right path. In order to explain this integrity, studies are carried out on the basis of the page arrangement regarding the interrelation between verses and chapters. Mentioned studies make important contributions to the commentary accumulation and as the real interrelation of Quran is with the environment of revelation and its addressees, it is understood that this issue should not be disregarded in the studies of interrelations of Quran.

Hz. Âdem-iblîs anecdote is told in the chapters of both Mecca and Medina, being more weighted in Mecca chapters. It is told in different sections of the anecdote that the devil did not prostrate itself before $\mathrm{Hz}$. Âdem because of its pride and stubbornness unlike angels, that it deceived Hz. Adem and Eve to reveal their genitals, that it cursed them, it obtained permission until doomsday to keep humans away from the right way, it will fight using various methods for attaining this goal, the reactions of angels when Hz. Âdem was made Khalifa and how they came to their senses.

When the sections of the anecdote is not read in the context of revelation-personality, it is thought that the anecdote repeats itself. However, when we understand related verses in their own context and in the frame of their addressees, it is seen that every part has a special meaning in the conditions of revelation. In the chapters of Mecca, it is told that stubbornness, jealousy and pride of polytheists who did not believe in Islam resembled to the attitude of the satan, deniers who adopted satan as protector circumambulated the Kaaba in a naked way by stringing along with it, they established wrong rules in eating and drinking, while the angels they idolized obeyed the rules of Allah they were subject to the satan's way, they were heretics and the genii they idolized would not help them in the last judgment and it is understood that polytheists were invited to repenting. It is explained ti the Prophet in the anectode that he should have perseverance and resolution in the right way and he shouldn't resemble to Hz. Adem. Methods of narration in these chapters demonstrate that the dynamic language and style of Quran changes according to the addressees.

In the section of the anecdote in the Bakara chapter, appointment of Hz. Âdem as khalifa by Allah, making him learn the names, the objective of the angels and their coming to senses are included. Primary addressees of these verses are the Jewish who were jealous because epistles and divine representation were given to the illiterate Arabs and who did not adopt Islam and became enemies of the prophet and Muslims for this reason. Among these, the addressees are especially the literate who deny that the epistles were true although they knew they were because the prophet told Israelis the historical events nobody else knew because they were written only in Jewish sources, which he learned via revelation. Although it is seen as if knowledge is constantly repeated in the Hz. Adem-iblîs anecdote, it is observed that the addressee and the message to be conveyed change in every context therefore there is no repetition.
\end{abstract}

As the aim of the study is to determine the importance of reading the anecdotes in the Quran by considering the revelation process and to determine the addresses and the messages of Hz. Âdem-iblis anecdote, classic and modern period discussions on the creation of Hz. Adem and the paradise he lived in were not included in the article.

Keywords: Commentary, Context, Revelation, Hz. Âdem, İblîs 